\title{
Political Dynamics in Organizational Identity Breach and Reconstruction: Findings from the Crisis in UNICEF Germany
}

\author{
Claus D. Jacobs* \\ University of Bern \\ KPM Center for Public Management \\ Schanzeneckstrasse 1 \\ 3001 Bern, Switzerland \\ Phone +41316315929 \\ claus.jacobs@,kpm.unibe.ch \\ Karin Kreutzer \\ EBS University \\ Chair of Social Business \\ Rheingaustrasse 1 \\ 65375 Oestrich-Winkel, Germany \\ Phone +4961171021412 \\ karin.kreutzer@ebs.edu \\ Eero Vaara \\ University of Oxford \\ Saïd Business School \\ Park End Street \\ Oxford, OX1 1HP, United Kingdom \\ eero.vaara@sbs.ox.ac.uk
}

\section{Acknowledgements:}

We are most grateful for the terrific editorial guidance by Jason Shaw as well as for the insightful comments of the three constructive anonymous reviewers. We are deeply indebted to all organizational members of UNICEF Germany (its volunteers, staff, top management and board) for their spirited debates over the years and for allowing us to witness these firsthand. This data set would not have emerged in the first place without Urs Jäger's most skillful coorchestration of the mission review process in conjunction with Emmanuelle Reuter's and Florian Überbacher's assistance in data gathering. We gratefully acknowledge Davide Ravasi's and Guido Palazzo's comments on earlier drafts. We also thank Dror Etzion, Anne-Claire Pache, Filipe Santos, Wendy Smith, and the participants of the oikos Entrepreneurship Academies 2013 and 2015 for their valuable feedback. Furthermore, we are grateful for the insightful comments received in research seminars at Saïd Business School in 2019 and at EBS in 2013. Also, we also wish to thank David Miller for language review. We gratefully acknowledge Steven Floyd's academic guidance and friendship throughout the journey of this project. Claus Jacobs gratefully acknowledges Swiss National Science Foundation Grants No. 119062 and 139199.

* Corresponding author. Authors listed in alphabetical order as they have contributed equally to the manuscript. 


\title{
POLITICAL DYNAMICS IN ORGANIZATIONAL IDENTITY BREACH AND RECONSTRUCTION: FINDINGS FROM THE CRISIS IN UNICEF GERMANY
}

\begin{abstract}
This paper elucidates the political dynamics of organizational identity breach and reconstruction. Drawing on the revealing case of UNICEF Germany, we develop a process model of four phases of identity breach and reconstruction: build-up of identity tensions, revelation of identity breach, identity reconstruction, and enactment of the reconstructed identity. Our analysis explains how each phase was characterized by specific political strategies employed by the managerialist and idealist organizational members, the effects of these strategies on the power balance and consensus/conflict over organizational identity, and how particular triggers explain shifts from one phase to another. By so doing, our analysis advances our understanding of organizational identity breach and reconstruction as political processes and paves the way for new studies of political identity dynamics in other contexts.
\end{abstract}

Organizational members are at times confronted with a need to revisit their identity beliefs, i.e. what the organization stands for from their perspective (Corley \& Gioia, 2004; Ravasi \& Phillips, 2011). This is especially the case with crises or scandals which culminate in overt struggles over organizational identity (Ashforth \& Reingen, 2014; Gioia, Price, Hamilton, \& Thomas, 2010; Kreiner, Hollensbe, Sheep, Smith, \& Kataria, 2015). A key issue at play in such settings is organizational identity breach, which we define as a perception of a violation of organizational identity beliefs among a group of organizational members.

Although prior research has elucidated the ways in which tensions characterize organizational identities (Ashforth \& Reingen, 2014; Corley \& Gioia, 2004; Kreiner et al., 2015) and offers us insights into breach (Glynn, 2000; Golden-Biddle \& Rao, 1997) and reconstruction (Howard-Grenville, Metzger, \& Meyer, 2013; Ravasi \& Phillips, 2011; Ravasi, Rindova, \& Stigliani, 2019), we lack integrative theoretical frameworks of organizational identity breach and reconstruction. In particular, there is a paucity of knowledge about the political dynamics involved. This is unfortunate, because not all organizational members or stakeholders share the same views about organizational identity or breaches thereof. In other words, a desired action for one actor may be a breach for another. This may manifest itself in intensive struggles over the nature of organizational identity - surfacing in organizational conflicts that are visible to internal and often external stakeholders (Ashforth \& Reingen, 2014; Besharov \& Smith, 2014; 
Glynn, 2000; Golden-Biddle \& Rao, 1997; Smith \& Besharov, 2019). However, we know little of how increasing tensions or outright violations mobilize actors and engage them in political activity to bring such 'breaches' to the attention of others. Similarly, there is a lack of understanding regarding how 'balance' or 'consensus' can be restored and identity 'repaired.' Thus, there is a need to draw on the political view of organizational identities (Alvesson \& Willmott, 2002; Kenny, Whittle, \& Willmott, 2016; Rodrigues \& Child, 2008) to illuminate how the political dynamics unfold in organizational identity breach and reconstruction.

In this view, politics consist of formal and visible as well as informal and behind-thescenes efforts to exercise influence to pursue one's interests in an organization (Clegg, 1989; Fleming \& Spicer, 2014). Rather than only examining specific acts of 'politicking' (conscious political efforts to pursue one's interests at the expense of others), we concentrate on the various purposive ways in which organizational actors deal with issues that are linked with their fundamental interests, as is the case with their identity beliefs (Kenny et al., 2016). In this paper, we focus on the political strategies used by the actors involved in identity work (Brown, 2015; Sveningsson \& Alvesson, 2003). These strategies can be defined as actions taken to pursue one's own identity beliefs and related interests to influence the prevailing views about organizational identity (Kenny et al., 2016).

What such strategies are and how they play out in organizational identity breach and reconstruction is still poorly understood. This would, however, be important to be able to better grasp how actors typically deal with breach, the political processes this likely induces, and how the actors may build new consensus about organizational identity. This leads us to formulate our research questions as follows: How do organizational politics shape the processes of organizational identity breach and reconstruction? What kinds of political strategies do organizational actors employ when wrestling with consensus and conflict over organizational identity? 
Our empirical analysis focuses on a revelatory case study of organizational identity breach and reconstruction at UNICEF Germany in 2007-2017. We gathered detailed empirical material in a longitudinal research project including participant and non-participant observation, interviews, internal documents, and media material. As a result of our analysis, we identified and elaborated on four phases of identity breach and reconstruction: build-up of identity tensions, revelation of identity breach, identity reconstruction, and enactment of the reconstructed identity. Our analysis reveals how each phase was characterized by specific political strategies employed by the managerialist and idealist organizational members and the effects of these strategies on the power balance and consensus/conflict over organizational identity. It also pays heed to the triggers explaining the shifts from one phase to another.

The contribution of this paper is that it advances our understanding of organizational identity breach and reconstruction as inherently political phenomena by revealing the underlying political dynamics and strategies involved. Thus, what could be seen from a cognitive or cultural perspective as an 'objective' breach (Ashforth \& Reingen, 2014; Besharov \& Smith, 2014) turns out to be a politically charged framing, and what could conventionally be viewed as identity 'repair' (Ravasi \& Phillips, 2011) is also a result of political negotiation. Our analysis not only offers these insights but also provides a process model that helps explain the typical political dynamics and strategies underlying organizational identity breach and reconstruction. In addition, by illuminating how these dynamics revolve around a delicate power balance in hybrid organizations, we specifically add to research on hybrid identities (Ashforth \& Reingen, 2014; Besharov \& Smith, 2014; Glynn, 2000; Golden-Biddle \& Rao, 1997; Smith \& Besharov, 2019). In particular, our case shows how a power struggle triggered by the idealists may lead to a reconstruction, thus offering a rare example of the idealists, if not 'winning,' then at least reaching a more favorable balance for them in the new reconstructed identity. Finally, 
by outlining this political view, our analysis complements the predominant cognitive and cultural perspectives on organizational identity more generally as called for in previous research (Kenny et al., 2016; Rodrigues \& Child, 2008).

\section{THEORETICAL FRAMEWORK}

\section{Organizational Identity Breach and Reconstruction}

The notion of breach has been used in several ways across social sciences. In sociology, the term was made famous by Garfinkel's (1967) "breaching experiments," and thereafter it has been used to describe the violations of commonly held understandings in a social group. In this view, breach is created by a violation of "interpretive trust" (Garfinkel, 1967), i.e. "a hole in the fabric of meaning" (Feldman, 1995: 68). In organizational behavior, the concept of breach has mainly been mobilized in the context of psychological contract breach at the individual level (Bankins, 2015; Coyle-Shapiro, Pereira Costa, Doden, \& Chang, 2019; Dulac, Coyle-Shapiro, Henderson, \& Wayne, 2008). Such contracts and perceptions thereof evolve over time and go through cycles of negotiation, breach and/or fulfillment (Bankins, 2015). In this respect, psychological contract breach refers to "a global cognitive appraisal of the extent to which prior transactions have not fulfilled the perceived promises of one's psychological contract" (Dulac et al., 2008: 1082). Thus, in analogous terms, identity breach at the organizational level may constitute a violation of a social contract regarding the - supposedly shared normative aspirations of the organization. Thus, we view organizational identity breach as a perception of a violation of organizational identity beliefs among a group of organizational members.

Although it has not often used this term, extant research in organizational identity has focused increasing attention on organizational identity breach and what it entails: tensions informing us about the antecedents of breach, violations helping us to understand how breach occurs, and repair offering examples of identity reconstruction following breach. First, there is increasing recognition that organizational identities are characterized by tensions. This body 
of work comprises several interrelated streams of research including work on ambiguity (Corley \& Gioia, 2004; Nag, Corley, \& Gioia, 2007), hybridity (Ashforth \& Reingen, 2014; Smith \& Besharov, 2019), and elasticity (Kreiner et al., 2015). Scholars have focused attention on ambiguity (Corley \& Gioia, 2004; Nag et al., 2007) as "interpretive instability" regarding an organization's identity that develops when organizational members lack a sense of coherence or consistency in their organizational identity beliefs. Such ambiguity has been found to explain problems and challenges encountered for instance in strategic change (Nag et al., 2007), technological change (Tripsas, 2009), mergers (Clark, Gioia, Ketchen, \& Thomas, 2010), and spin-offs (Corley \& Gioia, 2004). Research has also shown that organizational identity tensions are especially prevalent in hybrid organizations (Ashforth \& Reingen, 2014; Besharov, 2014; Golden-Biddle \& Rao, 1997; Smith \& Besharov, 2019), i.e. organizations "whose identity is composed of two or more types that would not normally be expected together" (Albert \& Whetten, 1985: 270).

Recently, scholars have introduced the notion of identity elasticity (Kreiner et al., 2015; Nag et al., 2007), which means "the tensions that simultaneously stretch, while holding together, social constructions of identity" (Kreiner et al., 2015: 981). Whereas elastic constructions of identity allow for a certain variation in identity attributes, inelastic constructions limit and constrict identity attributes (Kreiner et al., 2015: 985). Exploring the formation of a "contested hybrid," the first Islamic bank in Germany, Gümüsay, Smets, and Morris (2019: 36) identify "indisputable and persistent tensions between banking objectives and religious considerations." To cope with this specific institutional complexity, the organization engaged in "elastic hybridity," namely dynamic interplay between organizational arenas open for multiple meanings and individual enactments of competing logics.

Second, we also know that at times these tensions become untenable, some organizational members experience identity violations and thus breach occurs - even if scholars have rarely 
used this term per se (Ashforth \& Reingen, 2014; Besharov, 2014; Glynn, 2000; Golden-Biddle $\&$ Rao, 1997). For example, in the case of a not-for-profit medical organization, "hitherto latent contradictions in organizational identity" became manifest (Golden-Biddle \& Rao, 1997: 595). Here the pivotal event that triggered subsequent mitigation efforts consisted of non-compliance by a few board members with identity-conforming role expectations (Golden-Biddle \& Rao, 1997). Similarly, in the Atlanta Symphony Orchestra, organizational identity tensions built up over time - to a level where musicians experienced not only a threatened but a violated identity (Glynn, 2000). These "latent rifts" and "slumbering differences" between musicians and administrators culminated in the musicians' strike (Glynn, 2000: 286).

As long as ambidextrous, pluralist managers mediated the latent identity tensions in a socially responsible hybrid food retailer, tensions did not reach a threshold level (Besharov, 2014). However, when idealists witnessed incidents in which they saw their cherished organizational values of health, community welfare, and sustainability threatened, they took issue with what they perceived as a moral violation of the organization's identity. In yet another case, a hybrid natural food cooperative's inherent organizational identity tensions between idealism and pragmatism "were baked" into its "very DNA" (Ashforth \& Reingen, 2014: 502). As a coping strategy, organizational members cognitively split the hybrid mission and identified with their favored part, but the split resulted in a conflict "over realizing cooperative ideals vs. running a viable business" (Ashforth \& Reingen, 2014: 474).

Third, there is also a stream of work that helps us understand what happens after an experience of breach. As organizational identity breach is based on a sense of violation, organizational identity reconstruction is needed to restore a sense of cognitive or cultural coherence in organizational identity. Such identity reconstruction has been examined in research on identity threat responses (Elsbach \& Kramer, 1996), identity re-evaluation (Ravasi \& Schultz, 2006), identity reassessment (Ravasi \& Phillips, 2011), or identity resurrection (Howard- 
Grenville et al., 2013). For instance, Elsbach and Kramer (1996) identified two main identity reconstruction approaches in the responses of top US universities to the perceived identity threat posed by MBA Business Week's rankings: “emphasizing and focusing on their school's membership in selective organizational categories that highlighted favorable identity dimensions" and "interorganizational comparisons not recognized by the rankings" (Elsbach \& Kramer, 1996: 442). Based on a study of an identity crisis in a premium audio-video systems producer, Ravasi and Schultz (2006) developed a model of identity re-evaluation, involving reflection on cultural practices and artifacts followed by formulating and circulating revised identity statements. In the same organization, Ravasi and Phillips (2011) studied how a drift in the organization's identity was followed by identity reconstruction based on reassessment, reformulation of identity claims, and identity refocus to mitigate or even close the gap in identity discrepancy.

Exploring identity reconstruction in a construction toy manufacturer, Schultz and Hernes (2013) showed how evocation of the past shapes and informs identity reconstruction. When mobilizing the organization's past for identity reconstruction, organizational members used textual, material, and oral forms of memory. Concerned with the decline of a community identity, Howard-Grenville et al. (2013) have in turn developed the concept of identity resurrection as a form of collective identity reconstruction which aims at restoring a sense of coherence when "identity claims and understandings gradually lose salience, as a result of not being actively asserted or experienced" (Howard-Grenville et al., 2013: 116). Attributing the pivotal role in reconstruction work to formal leaders, their model conceptualizes identity resurrection through a resourcing lens; community leaders marshal tangible and intangible resources including authentic and emotional experiences to recreate a sense of coherence in community identity. 
Thus, extant research offers us a number of insights into the social processes that play a key role in organizational identity breach and reconstruction. These studies highlight key aspects of organizational identity tensions, offer examples of how breach occurs, and provide models of how identities may be repaired. However, our understanding of the political dynamics underlying breach and reconstruction is still very limited and lacking conceptual models. In particular, there is a paucity of knowledge of how the increasing tensions or outright violations may get specific actors mobilized to bring the 'breach' to the attention of others. Similarly, we have only begun to comprehend the confrontational dynamics that follow the revelation of breaches. There is also a lack of understanding of how a 'power balance' may be restored so that organizational identities may be 'reconstructed.' To dig deeper into these processes, there is thus a need to adopt a political perspective that helps us see organizational identities as inherently political constructs and develop understanding of the various strategies organizational actors may use when dealing with organizational identity breach and reconstruction.

\section{A Political Perspective on Organizational Identity Breach}

Power and politics are inherent parts of organizational reality that can be approached from various theoretical and onto-epistemological perspectives (Clegg, Courpasson, \& Phillips, 2006; Fleming \& Spicer, 2014; Willmott, 2013). In organization studies, scholars such as Pfeffer and Salancik (1974) have conceptualized power as residing in individuals and showing in struggles over resources - thereby focusing on the overt politics showing in politicking between various actors. In contrast, informed by the seminal work of Foucault (1980) and Lukes (1974), others such as Willmott (2013) have focused on the more 'hidden' aspects of power linked with ideology or hegemony. In this view, power is seen as relational, omnipresent, and intimately linked with subjectivity and identity.

This has made scholars conceptualize power as a multifaceted phenomenon (Clegg, 1989; Fleming \& Spicer, 2014; Lukes, 1974), which is the perspective we follow in this paper. 
More specifically, we follow Fleming and Spicer's recent review of power and politics (2014: $239)$ in explaining how power and politics are linked together: "[P]olitics consists of activity that rearranges relations between people and the distribution of goods (broadly defined) through the mobilization of power. In turn, power is the capacity to influence other actors with these political interests in mind." In practice, this is shown in the processes and practices of organizational actors that challenge, contest and oppose others - which in turn mobilize to counter these challenges (Clegg et al., 2006). This view helps us avoid portraying politics as an 'irrational' or 'illegitimate' part of organizations but seeing it as an ever-present aspect of organizational life. However, such a comprehensive view needs unpacking, and this is why it is useful to focus on the specific aspects of politics relating to organizational identity work (Alvesson \& Willmott, 2002; Sveningsson \& Alvesson, 2003) in the context organizational identity breach and reconstruction.

Unfortunately, with its focus on cognitive or cultural aspects (for reviews, see Brown, 2020; Brown, 2015; Gioia, Patvardhan, Hamilton, \& Corley, 2013b; Pratt, Schultz, Ashforth, \& Ravasi, 2016), research on organizational identity has rarely focused on power and politics. Rather than organizational identity, the more explicit analyses of politics have tended to concentrate on either individual, occupational, or professional identity work (Alvesson \& Willmott, 2002; Sveningsson \& Alvesson, 2003) or on the identification of individuals with the organization (Brown, 2020; Brown, Kornberger, Clegg, \& Carter, 2010). Thus, extant studies on organizational identity tend to pay little attention to political aspects of organizational identity; power and politics have consequently remained relatively undertheorized and underexplored themes in organizational identity scholarship as pointed out in recent reviews (Pratt et al., 2016).

There are, however, exceptions. For instance, Glynn (2000) argues that identity construction is "typically conducted by a group of social actors to persuade an audience to accept their 
construction of a problem as legitimate and, thus, their proffered solution." It is accordingly a "sociopolitical process" of meaning negotiation whereby the powerful coalition "regulates meaning - and conveys this meaning in their rhetoric" (Glynn, 2000: 286, 294). When exploring development of the corporate identity of a Brazilian telecommunications company, Rodrigues and Child (2008) premise their empirical analysis by identifying a "tacit insistence on an apolitical treatment of what is a politically charged topic" as a key limitation of "current discourse on organizational identity" (Rodrigues \& Child, 2008: 887). Thus, a political view can accept and acknowledge that "definitions of an organization's identity derive from subjective interpretations but it would expect such interpretations to be informed by a sense of how that organization can serve the interests of the people concerned" (Rodrigues \& Child, 2008: 888).

In a rare theoretical paper on power in organizational identity, Kenny et al. (2016: 2) have in turn argued that "to de-mystify organizational identity, it is necessary to appreciate how power and politics are integral to, and deeply embedded in, processes of its (re)production." In this view, organizational identity conveys a sense of unity, but such unity is at best partial, conditional, or instrumental. Thus, this unity is not 'natural' but tends to reflect specific interests and viewpoints at the expense of others. Kenny et al. (2016) also argue that this is why organizational identities as constructions tend to reproduce specific power relations or even structures of domination or hegemony. This leads us to suggest that organizational identity can be viewed as an inherently political construction, which manifests a specific kind of consensus and conflict that more or less masks different interests or viewpoints.

But how do the actors then pursue their interests, more specifically their identity beliefs, in organizational identity breach? To be able to understand the specific dynamics about organizational identity breach, we focus on the political strategies used by the actors involved in identity work (Brown, 2015; Sveningsson \& Alvesson, 2003). These political strategies are 
thus not any kind of political action, but they are actions taken to pursue one's own identity beliefs and related interests to influence the prevailing views about organizational identity.

Thus, we adopt a broad view on such strategies in that they do not have to imply very clear, conscious, or deliberate strategizing but rather efforts to deal with the experienced breaches and work towards reconstruction. Wodak et al. (1999: 32) explains the nature of these identity strategies as follows: "Strategic action is oriented towards a goal, but not necessarily planned to the last detail or strictly instrumentalist; strategies can also be applied automatically." Thus, political strategies can be seen as means to promote one's own identity beliefs and values, to deal with those of others, and to create new identity constructions. However, to date, we lack specific understanding of the strategies employed in organizational identity breach and reconstruction.

In this view, the processes of organizational identity breach and reconstruction involve political dynamics between organizational members who use distinct strategies to challenge and critique specific identity beliefs and values as well as to defend or propose others. In such processes, intra-organizational coalitions, alliances, and networks between different groups, positions, and functions may be formed especially in response to identity threats or outright breaches (Glynn, 2000; Petriglieri \& Devine, 2016). However, interests are not fixed in the sense that people would always belong to a specific group or coalition. Instead, identification with particular interests and viewpoints may also be context-specific and change over time.

These processes may involve shifts and restorations of power balance between key actors and the identity beliefs they hold and wish to promote. This is especially the case with hybrid organizations that need to deal with a balance between more idealist and pragmatic concerns (Ashforth \& Reingen, 2014; Besharov, 2014; Glynn, 2000; Golden-Biddle \& Rao, 1997). Developments distorting the power balance between such groups may be a key reason for the 
experience of identity violations and subsequent mobilization or political action by the 'underdogs.' Sometimes, the tensions and conflicts in the identity constructions are more obvious, and this is the primary reason for the need to adopt a political perspective on organizational identity breach. However, it is not only the overt struggles in breach that are manifestations of politics; any consensus on organizational identity preceding breach or reconstructed thereafter is also a product of power and politics. This is the key insight required to fully comprehend the political dynamics driving breach and reconstruction. Furthermore, taking aspects of organizational identity for granted can be seen as the ultimate exercise of power resembling ideological reproduction or hegemony in theories of power (Kenny et al., 2016; Rodrigues \& Child, 2008).

In summary, our understanding of the political dynamics of organizational identity breach and reconstruction is limited. In particular, there is a lack of understanding of how organizational actors are mobilized or engaged to deal with what they see as breach and how this may lead to a new negotiated reconstruction of the organizational identity. Thus, elucidation of these process dynamics is the intended contribution of our paper. We will now turn to the revealing empirical case of UNICEF Germany to develop understanding of the political dynamics of organizational identity breach and especially the strategies that the actors use in these processes.

\section{CONTEXT AND METHODS}

\section{Research Context}

The case of UNICEF's German National Committee (hereinafter UNICEF Germany) 2007-2017 provides us with a revealing setting for investigating organizational identity breach and reconstruction from a political perspective. This is because the organization went through a period of turmoil in which many organizational members experienced a violation of their idealist organizational identity beliefs and values - while others chose to defend and justify the prevailing managerialist beliefs and values. 
Working under the auspices of the United Nations General Assembly, UNICEF International is guided first and foremost by the Convention on the Rights of the Child and fosters the survival, protection, and development of children worldwide (OHCHR, 2019). UNICEF International is headquartered in New York (USA) and has project sites over the globe, primarily in the global south. Today, 34 National Committees are an integral part of UNICEF's global organization. Contributing one-third of UNICEF's annual income, they are legally independent local non-governmental organizations, serve "as the public face and dedicated voice of UNICEF," raise funds, and promote children's rights (UNICEF, 2019).

UNICEF's German National Committee is based in Cologne and at the outset of our study had an HQ staff of 90 and more than 8,000 volunteers organized in more than 150 groups throughout the country. Traditionally, the spouse or partner of Germany's president serves as patron of UNICEF Germany. The organization's purpose has been to both inform people in Germany about children's welfare and to promote their rights and support UNICEF's international program work by raising and forwarding donations and funds. Established in 1953 as an association under German law, UNICEF Germany is legally independent yet formally affiliated with UNICEF International through a collaboration agreement.

UNICEF's national committees enjoy a fair amount of autonomy. For instance, the committees are free in their choice of legal form, which national strategies to employ, how to structure their operations, how to combine fundraising and merchandizing, or whether to involve volunteers. UNICEF Germany's steering bodies consist of a co-optation-based, 72-member assembly that elects a supervisory board of 10 directors (hereinafter the board), typically consisting of volunteers who jointly oversee activities, approve the budget, and appoint the top management team (consisting of the CEO and the five heads of the divisions of finance, marketing, fundraising, child rights advocacy, and volunteers' management; hereinafter TMT; see 
the Online Appendix for a graphical representation of the organizational structure and key constituencies).

The board's composition reflects a broad range of societal groups, including members of parliament from all political parties, business and media representatives, as well as delegates of the volunteer groups. With brand recognition of over $90 \%$, UNICEF was among the bestknown and trusted brands in Germany prior to the crisis in 2007. Just before the crisis, UNICEF Germany raised approximately 90 MEUR in income every year (UNICEF Germany, 2007) from which national operational costs are covered and any surplus transferred to UNICEF International.

We entered the organization in May 2008 when it was facing a crisis linked with allegations of fraud first publicly aired by an internal whistleblower in late 2007. Although this happened before the global financial crisis broke in the fall of 2008, the global events may have added to the sense of crisis within and around the organization later in 2008. Despite the global financial market crisis, the overall German fundraising market grew by approximately $3.9 \%$ in 2008 (Spendenrat, 2009). Against this market trend and likely related to the crisis, UNICEF Germany experienced a 24\% decline in income in 2008 (UNICEF, 2009). Moreover, the organization soon lost the "trusted charity label ("DZI Siegel”), a highly relevant accreditation indicating the trustworthiness of a given charity to potential donors.

Most importantly for our purposes, at the heart of the crisis was largely a political struggle over its identity, which we later conceptualized as organizational identity breach. During this time, organizational members - both members of the staff and volunteers - voiced the need for gaining a renewed sense of purpose and direction, which was a key part of the organization's efforts to deal with the crisis. As a consequence, the interim CEO 2 initiated a participatory, inclusive mission review process, which offered us unique access to this organization. Developing mission statements typically involves surfacing and discussing the most important traits 
and characteristics that members believe the organization stands for - i.e. its organizational identity.

Our research team consisted of six individuals in total. The first and second authors have been involved with the organization since 2008 in different capacities. Together with another colleague, the first author participated as a facilitator in the organization's mission review process. The second author and two research associates acted as non-participant observers by documenting workshops, strategy retreats, and board/executive meetings or conducting interviews with our informants. The third author did not have any exposure to the organization or its informants but has later acted as a critical peer reviewer in our case analysis.

Figure 1 provides a timeline for the case, including key events and actors as well as what we identified as phases of identity breach and reconstruction (see step 4 in analysis below).

\section{Empirical Data}

Insert Figure 1 about here

Our empirical data comprise participant and non-participant observations of a number of meetings and workshops, several rounds of interviews, organizational documents such as internal reports, minutes, and slide decks as well as media texts covering the period from 2007 to 2014. Real-time data were collected between May 2008 and May 2014 and retrospective data were used to cover the initial phases of our analysis. Furthermore, we supplemented this empirical material with follow-up data for 2015-2017. Table 1 provides an overview of our data sources.

\section{Insert Table 1 about here}

Observations. Observing and documenting the mission review process formed the initial core of our study. Between January and June 2009, we observed and documented eight mission review workshops. Two of these comprised the entire board, the CEO, and TMT. Three workshops were conducted with key constituencies of the organization, namely representatives of the volunteers, HQ staff, and representatives of the association's assembly. Another three cross- 
constituency workshops with representatives of the former three constituencies were conducted to compare, contrast, and integrate the various perspectives before submitting these findings to the board and management team. The workshops involved exploring the relevant themes provided by participants, structuring them according to tensions or contradictions, and finally discussing and agreeing on future positioning. The final workshop with the board and executive team would then take these findings into account in defining the new mission statement, i.e. the approved representation of the organization's identity.

We also followed a number of board and top management meetings as well as strategy retreats. For instance, we participated in three strategy retreats in 2009, 2011 and 2012 where the first author facilitated the sessions and the second author documented what was going on. In total, we observed 27 formal events (board and top management meetings, strategy retreats, workshops). In addition, we attended numerous conference calls and had informal conversations in the hallway, over coffee and lunch, and when traveling together. Detailed fieldnotes were taken to document our observations during all these events.

Interviews. Over the course of our data gathering, we conducted 44 semi-structured interviews in four rounds. The interviews lasted 60-90 minutes and were recorded and transcribed verbatim. In the first round of interviews in 2008, we interviewed the members of the board and top management, the long-time (pre-crisis) Chairperson 1 of the board, interim CEO 2, his two successors (CEOs 3 and 4), as well as the five heads of divisions. We were interested in how interviewees made sense of the whistleblowing, the media 'storm,' and the crisis overall. Furthermore, we asked participants about their views on the organization's goals, actions, and other cultural and identity-related phenomena and how these were perceived by key internal and external stakeholders. We also explored how interviewees conceptualized the crisis, its history and root causes as well as the critical events prior to and during the crisis. 
After approval of the new mission statement and subsequent endorsement of the organization's new strategy by the board in 2010, we engaged CEO 4 and the five division heads in a second round of interviews. This time we followed up on the themes raised in the first round but then supplemented these follow-ups by exploring which actions, discussions, and events may have led to some form of change. We also invited them to reflect on their own role in this process. In a third round of interviews in 2011, we again tracked the initial themes, the subsequent actions as well as our interviewees' roles and what they deemed critical to the adaptation and change that occurred after the crisis. To supplement and contextualize our core analysis, we conducted a fourth round of interviews to shed light on the long-term consistency of UNICEF's identity construction in top and middle managers. In addition, we had informal conversations with a number of organizational members on all hierarchical levels.

Documents and media coverage. We also gathered relevant internal documents comprising of meeting minutes, slide decks, handouts and other materials from board and top management meetings or workshops. Furthermore, we collected strategic planning reports including slide decks for 2009-2017 and annual reports for 2007-2017. In addition, we tracked eight German dailies (Aachener Zeitung, Frankfurter Rundschau, Frankfurter Allgemeine Zeitung, Kölner Stadtanzeiger, Kölnische Rundschau, Süddeutsche Zeitung, die tageszeitung, Die Welt) and four weeklies (Focus, Stern, Spiegel, Zeit) for the period 2007-2014 amounting to more than 250 articles concerning UNICEF Germany in total. We then zoomed in on 50 articles, which focused on the identity breach and reconstruction aspects of the crisis.

\section{Data Analysis}

Our analysis was characterized by an abductive approach that involved iterations between our theoretical understanding and the emerging results of our analysis (Ketokivi \& Mantere, 2010; Locke, Golden-Biddle, \& Feldman, 2008; Van Maanen, Sørensen, \& Mitchell, 2007). Initially, we were interested in how this organization forms an organizational identity 
orientation (Brickson, 2007) in and around the mission development process. However, we soon realized that this was rather a case of identity breach and the organization's related attempts to reconstruct the violated identity.

\section{Step 1: Analysis of identity-related themes and patterns}

In the first stage, we analyzed identity-related themes and patterns in our empirical material to chart the broader issues at play in our case. Specifically, we searched for data about what organizational members considered core to their organization's identity, what members perceived as tensions, violations, or breaches of the organization's identity, and how they made sense of efforts to reconstruct organizational identity. We coded all data with MaxQDA in an open coding approach (Strauss \& Corbin, 1998) using “in vivo" labels wherever possible. In total, we created approximately 100 emergent codes first independently and then in a process of constant comparison. We inductively developed first-order concepts which we then aggregated into more abstract, theory-informed second-order themes (Gioia, Corley, \& Hamilton, 2013a; Langley \& Abdallah, 2011). We developed visual maps and graphical displays to theoretically frame, organize, and reduce our data for analysis.

\section{Step 2: Analysis of the political dynamics at play}

After several iterations, prompted by the comments received, we realized that UNICEF Germany can be seen as a hybrid organization dealing with endemic identity tensions and politics (Albert \& Whetten, 1985; Ashforth \& Reingen, 2014; Besharov, 2014; Glynn, 2000). Such tensions and politics, and in the end, conflict of interests in terms of organizational identity, reside in distinct, often conflicting value systems enacted and voiced by organizational members. In this regard, UNICEF Germany demonstrated two distinct value systems that we labeled 'idealist' and 'managerialist.' While the idealist perspective endorses and emphasizes the normative aspects of the organization's mission (advocating the rights of children as well as edu- 
cating and engaging the public), the managerialist perspective foregrounds the utilitarian, economic aspects of the organization's mission (raising funds for UNICEF's global south projects, developing the brand, marketing UNICEF products, partnering with business and media).

For our representation of these political struggles over identity in the case analysis, it is important to note that we consider the two orientations - idealist or managerialist - not as inherent characteristics of individual actors but rather as transpersonal perspectives manifest in discursive repertoires available to any organizational member. For the sake of readability and as exemplified by related studies (Ashforth \& Reingen, 2014; Besharov, 2014), we attribute a political stance - idealist or managerialist - to key persons if they primarily advocated one or the other perspective. Volunteers, their representatives on the board (including Chairpersons 1 and 2), and HQ employees working for the volunteer and child rights advocacy divisions more often than not voiced idealist beliefs and values. In turn, most of the members of top management before the crisis (including CEO 1), board representatives with a business background (such as Chairperson 3), and employees at HQ working in the fundraising, financial, or marketing divisions oftentimes expressed a managerialist viewpoint. In deference to our confidentiality agreement with the organization, the actors cited below are presented in anonymized form.

\section{Step 3: Analysis of the effects of political strategies on power balance and consensus/con-} flict

Against the backdrop of these distinct political orientations, we proceeded to identify and elaborate on specific political strategies employed by the various actors. As to the build-up of identity tensions, we found that 'normalizing specific identity beliefs' (used by the managerialists to promote their beliefs at the expense of the idealist ones) and 'masking controversial practices' (employed by the managerialists to conceal activities that could be resisted by the 
idealists) were the key political strategies used. For revelation of identity breach, the core strategies were 'revealing identity violations' (the core strategy used by the idealists including whistleblowing (Kenny, Fotaki, \& Vandekerckhove, 2020)) and 'defending prevailing identity beliefs' (employed by the managerialists to counter the allegations and protect their identity beliefs). Political strategies contributing to identity reconstruction included 'arguing for alternative identity constructions' (used by both sides to promote their beliefs and values), and 'forging a compromise on identity' (a strategy where the two sides came together). When the reconstructed identity was enacted, the political strategies employed included 'enforcing the compromise' (a strategy used by the dominant coalition consisting of both sides to make sure the new identity would be adopted in the organization) and 'maintaining the compromise' on identity (a strategy used by both sides to ensure that the compromise would reflect their interests).

After some iterations, we focused on the effects of these strategies along two key dimensions: power balance and consensus/conflict about organizational identity. During the build-up of identity tensions, we observed a 'distorted power balance' that had sustained over a long period of time while a 'disguised conflict' kept simmering. When revealing the breach, however, there was a 'reversal of power balance' for the benefit of idealists in an 'open conflict' over identity. In our case, subsequent reconstructing of the organization's identity resulted in 'restored power balance' in an 'orchestrated consensus.' During the enactment of the reconstructed identity, the focus was on 'effectuation of balance' and 'sustained consensus.' After several iterations, we were able to move from first-order themes and second-order categories (political strategies; effects on power balance and consensus/conflict) to the four aggregate dimensions that form the distinct phases of our conceptual model. Figure 2 provides a summary of our key concepts and data structure. 


\section{Step 4: Developing a process model}

Our final step was to develop a theoretically and empirically grounded process model to theorize the politics of organizational identity breach and reconstruction. Building on the second order themes and the aggregate dimensions, we analytically theorized from the case to a more general model. The model comprises four phases of organizational identity breach and reconstruction detailing political strategies that result in phase-specific configurations of power balance as well as consensus/conflict over identity in each of them.

Our approach to field access and data gathering warrants critical reflection. The first and second author in collaboration with another colleague were involved with the organization in various capacities - including pro bono and paid process consultation. In acknowledging the challenges of what has been referred to as the involvement paradox (Langley \& Klag, 2019; Lüscher \& Lewis, 2008; Schein, 1995), we opted for the advantages of this unique field access. However, we also strove to mitigate the obvious risk of bias in several ways. First, we assigned clear roles and responsibilities every time we engaged with the organization. For instance, when the first author facilitated a workshop, a research associate was assigned to take fieldnotes and write up his or her observations. Second, we deliberately extended our data gathering beyond the narrow focus of a project assignment by observing management and board meetings and presentations by experts and consultants as well as by conducting interviews with key actors of the organization. Third, when interpreting and analyzing the observational and interview material, we focused special attention on our relationships with our informants and the potential implications of social desirability and other biases related to our involvement. What helped a great deal was that we could complement specific pieces of information with other types of data. Fourth, as the third author did not have any contact with or exposure to the organization, he was in a perfect position to question and challenge our coding, analysis, and conclusions systematically and throughout the research collaboration. 


\section{POLITICAL DYNAMICS OF IDENTITY BREACH AND RECONSTRUCTION IN UNICEF GERMANY}

Based on our analysis, we developed a process model of organizational identity breach and reconstruction consisting of four phases characterized by specific political dynamics: build-up of identity tensions, revelation of identity breach, identity reconstruction, and enactment of the reconstructed identity. In each phase, the key actors - in our case managerialists and idealists - employ specific political strategies to advance their identity beliefs and related interests. This leads to a particular kind of power balance and type of conflict or consensus about organizational identity in each phase. In the build-up of identity tensions, the balance becomes distorted, but the conflict remains largely disguised; in the revelation of identity breach, there is an attempt to reverse the balance in open conflict; in identity reconstruction, the balance is restored in orchestrated consensus; and in enactment of the reconstructed identity, the balance is effectuated and consensus enforced. There are also triggers that explain the shifts from one phase to another: increasing tensions reaching a breaking point, crisis creating pressure for reconciliation, and urge to conclude reconstruction and to move on. Although in our case this is not fully demonstrated empirically, the enforced consensus established in identity reconstruction may also hold the seeds and risk of developing a one-sided identity (arrow down below). Figure 3 below offers a summary of the model.

Insert Figure 3 about here

\section{Phase 1: Build-up of Identity Tensions}

\section{Political strategies: Normalizing identity beliefs and masking controversial practices}

Over time, a managerialist coalition - led by the CEO 1, the head of fundraising and other members of top management - had acquired a strong power position in the organization. To a large extent, they controlled decision-making and agenda-setting in the organization. Thus, the managerialists could draw on their power position to make UNICEF a more "business-like" 
and "professionally run organization" - thereby promoting managerialist identity beliefs and values at the expense of the idealist views. This involved political strategies such as normalizing specific identity beliefs and masking controversial practices. Table 2 below offers an overview of these strategies.

Insert Table 2 about here

Normalizing specific identity beliefs. Managerialists such as top management members focused on normalizing new business-oriented identity beliefs. Thus, the focus of organizational attention was on fundraising, marketing, brand recognition and related matters. In particular, fundraising outcomes became a key topic of internal and external communication. The results were impressive; the organization quadrupled its income from 1989 to 2007, with the 2004 Tsunami leading to the highest donations in the organization's history. This also involved introducing new business practices such as external consultants and performance-based fundraising mandates. Continuous economic growth further increased the power of top management to place even larger emphasis on fundraising activities. A former board member recounted this shift vividly: "Witnessing the growth of UNICEF from a 25-million to a 100-million charity was probably the most astonishing change during my 20-year tenure."

This shift in organizational focus was justified by an overall 'market trend' in fundraising for not-for-profit organizations, as a board member recalls: "It [emphasis on managerialist beliefs and values] was a normal process of professionalization. Things [the market] were developing towards efficiency and business practices in the nonprofit sector. UNICEF was growing so we adapted our structures accordingly." (Interview, board member, 2008). Furthermore, revenues became the benchmark in Germany as well as for the internal market of contributions by national committees to UNICEF International.

Importantly, this financial success enhanced the power position of the managerialists in general and of the CEO 1 in particular: "The CEO could do whatever he wanted. There was no 
controlling body in place." (Interview, board member, 2008). Specifically, the board did not seem to be able to exercise control over top management. As a managerialist top manager recalls, "The board was composed of many members with a strong interest in development cooperation and children's rights. The business aspects of our work were not addressed [and thus not questioned] in board meetings." (Interview, top manager, 2008). A volunteer representative of the board compellingly echoes this view: "Everything was going well in financial terms; donations were coming in, so everything had to be fine. It was too convenient not to focus on those [business-related] topics."

In contrast, alternative views on organizational identity were ignored, and the idealist managers, staff members and volunteers felt sidelined and losing their influence. In particular, activities such as advocacy, information, and engagement of volunteers were somewhat backgrounded in internal and external communication. A managerialist top manager explained the rationale for ignoring such aspects: "There are people in the organization who are very mission-driven [idealists]. Someone suggested we should be selling hand-made dolls from a Mexican cooperative. We have a turnover of almost 100 million euro. We cannot listen to every kind-hearted individual who wants to do good. These people are too far away from the realities of our daily business." (Interview, top manager, 2008). Thus, while the managerialist identity beliefs were normalized, the idealists' beliefs were increasingly sidelined.

Masking controversial practices. More or less deliberately, some of the new practices were hidden from the idealist volunteers in different parts of the organization. A key part of it was the 'compartmentalization' in the organization. The CEO 1 formed a coalition of loyal followers, mainly fundraisers, who shared his managerialist point of view, and these people became the 'inner circle' sharing the information and making the key decisions. As a top manager reflects, the volunteers were "dissatisfied because they felt they did not get enough infor- 
mation, enough insights into our work at headquarters. ” Moreover, there had been "a discrepancy with regard to the perception of the organization ... Very few [volunteers] had seen UNICEF as a really big organization with professional methods."

In particular, top management and HQ staff tended to disguise practices that they expected to be controversial. As one of the top managers explains, "Yes, we do have fundraising arrangements where we pay a commission fee on each large donation raised. But we cannot explain this to our volunteers, they wouldn't understand it. Rather, they would challenge it as money that does not benefit children directly. They might even consider such a fee unethical." This also created uneasy situations such as the one described by a key manager: "When I was asked to provide copies of the consulting contracts, there was silence [by the managerialists], even suspicious silence [since nobody talked to her about the contracts for a month]. Maybe it was the calm before the storm." (Interview, top manager, 2008). Thus, rather than taking the risk of having their choice of fundraising practices challenged by volunteers, HQ staff chose to conceal it.

With the managerialist coalition controlling the agenda, voicing of alternative beliefs and values was risky as it was counter to the implicit expectation of complying with the new managerialist orientation. According to an idealist board member, unsolicited inquiry was not advised: “There was 'harmony' amongst us, nobody wanted to disturb that. If you asked a critical question it was perceived as disruptive." One idealist manager framed this as a cultural-political phenomenon of unspoken rules and expectations of what to say and what not to say. He called it "a culture of the implicit." In this view, "explicating things was perceived as countercultural and threatening." As another board member recalls, "problematizing any inherent tensions was taboo." (Interview, top manager, 2008). While this strategy of masking controversial practices seemed helpful from top management's perspective in short run, it had, however, drastic effects in adding to the gravity of the crisis as experienced in Phase 2. 


\section{Political effects: Distorted balance and disguised conflict}

Distorted balance. As a result of normalizing managerialist identity beliefs and ignoring of idealist beliefs, the balance of power became distorted in the organization. Increasingly, the prevailing beliefs and values reflected managerialists' interests, not those of the idealists. In particular, new business-like beliefs and practices were prioritized. The following quote by one of the top managers demonstrates the shift to managerialism as the widely accepted 'new normal': "Volunteers are a mixed blessing. ... Adhering to their needs is expensive and makes our daily job at HQ harder. While we need them, we need to stop pretending that their importance is exclusive." (Interview, top manager, 2008). At the same time, the idealists felt disenfranchised by being "sidelined," "ignored," and "lacking voice." "Our [idealist] topics were not on the agenda. We had to actively fight to legitimize activities that would not generate revenues but were geared to fulfill our social mission." (Interview, top manager, 2008). This was the key reason for the built-up of tensions to the extent that they would eventually reach a breaking point.

Disguised conflict. The conflict was, however, largely an underlying one for a long time. A major reason for this was the masking of controversial practices. While it seemed helpful from top management's perspective in the short run, it had dramatic effects in the longer run. This is because the extent to which managerialist beliefs and practices had become to dominate the organization was not evident to the majority of the organizational members, adding to the gravity of revelation of breach in Phase 2. Thus, many idealist members realized only during the subsequent crisis "how 'business-professional' the UNICEF headquarters had become ... in terms of their investment logic and other business-like behavior, " as an idealist board member recalled.

In any case, the politics of the managerialists led to a growing sense of dissatisfaction among the idealist-oriented volunteer base, likeminded managers and staff of the organization. 
A key informant explained it as follows: "I was surprised that ... the board [including key idealist representatives] did not move quicker on the CEO. He had complete managerial discretion, no restriction, but was extremely successful. But the board hesitated to restrict his power." The sense of surprise vividly shows how the managerialists' strategies kept the tensions growing under the surface - until they reached a break-up point triggering Phase 2.

\section{Phase 2: Revelation of Identity Breach}

\section{Political strategies: Revealing identity violations and defending prevailing identity be-}

liefs

The second phase saw the revelation of the organizational identity breach when the tensions experienced by idealists reached a breaking point. Thus, started by an idealist whistleblower, the idealists got mobilized to resist what they had experienced as identity violations and to restore the overall balance of power. The political strategies employed by idealists consisted mainly of revealing identity violations whereas managerialists in turn engaged in defending the prevailing identity beliefs. Table 3 provides an overview of these strategies.

Insert Table 3 about here

Revealing identity violations. An idealist whistleblower - according to Chairperson 2 a "frustrated soul" (Der Spiegel, November 28, 2007) - approached first the board, and then a media outlet. The letter can be seen as the initial political move to reveal the identity breach. As a board member recalls, "This power configuration [inactive board, powerful managerial coalition] worked well until the anonymous letter was written. I have it over there, the letter attacking our CEO and that he is abusing donations, spending too much money for the new headquarters, etc.” (Interview, board member, 2008). Based on the whistleblower's information, CEO 1 was alleged to have committed fraud and misappropriated funds in the context of a major renovation of $\mathrm{HQ}$, external consulting arrangements, and corresponding formalization of internal processes (Frankfurter Rundschau, November 28, 2007). This whistleblowing 
and its subsequent media coverage made identity breach the subject of a public debate. Other national media outlets quickly picked up and diffused stories about "the scandal" for the following four months.

Key idealists (including Chairperson 2 and volunteers) joined the public debate. In this discussion, the problems were framed as severe violations of what UNICEF Germany should stand for. The use of external consultants was in the focus of the discussion: "It's hard to understand how "external consultants" would earn these enormous amounts of money and the volunteers work for free. This money comes directly from our donors." (Observation, hallway conversation, idealist board member, 2008). Another key violation was the money spent on renovation of the HQ: "There was never an open vote about the renovation of headquarters. They almost spent 1 million euro." (Interview, idealist board member, 2008)

According to a top management team member, the volunteers could not "believe what happened, they were so far away from our day-to-day business at headquarters, they didn't know how to evaluate the situation." Experiencing a mix of outrage and disappointment about the identity violations, volunteers continued to send letters to editors critical of the business orientation and practices - often using UNICEF corporate stationery. Volunteers oftentimes voiced their sense of identity violation in moral terms: "It's not about breaking the law or whether the processes are "lawful." It's about the social values, moral and ethical principles which the CEO of such an organization must adhere to" (Frankfurter Rundschau, January 18, 2008). Explaining her frustration to a local newspaper, another volunteer had the following to say: "I have been supporting UNICEF for years, but I was horrified when the allegations became public.” (Aachener Zeitung, December 4, 2007).

The revelation of identity breach also involved challenging the prevailing identity beliefs and practices in different arenas. For instance, an idealist member of the board criticized commission fee payments for fundraisers: "Now, we have volunteers who go to great lengths to 
help UNICEF in any way they can - but do not get paid for it. As we are not a firm, we cannot at the same time pay commission fees for fundraising." Thus, a core theme consisted of idealists explicitly demarcating which aspects of the prevailing identity they strongly disagreed with and wished to have dropped from the organization's identity. Overall, revealing identity violations internally and externally proved to be an effective political strategy employed by idealists to challenge the status quo and to make a dent in the prevailing organizational identity construction.

Defending prevailing identity beliefs. Managerialist members of top management and board were in turn shocked about the allegations. As one of the top managers put it, "There have been volunteers who have strongly opposed the organization without even considering that they could actually harm their own organization." (Interview, top manager, 2008). Many members of the HQ staff were equally horrified by the revelations since "you arrived in the office in the morning and were not sure what the latest revelation would be." (Interview, top manager, 2008).

The managerialists defended their own view of the organization's beliefs and practices. One top manager defended current practices by questioning the critique and public outrage: "There was no relation between what was really objectionable and the reaction to it. Yes, there were minor misdemeanors but the reaction to them was out of proportion." Directly addressing the criticized external consulting mandates, a managerialist organizational member explained that these business practices were important parts of "regular projects and services" and were "standard practice" in similar organizations (Die Zeit, January 31, 2008). Members of the board also emphasized the necessity of fundraising: "Ultimately, we are a fundraising organization that helps UNICEF International fund its projects." On the same note, a managerialist top manager noted: "Fundraising is a very competitive market. You have to fight for every penny." (Observation, top manager, mission development workshop, 2008). With the intention 
to calm the frustrated idealists and defend the business practices, Chairperson 1 characterized the much-criticized business practices as "a necessary form of organizational modernization" (Die Zeit, January 31, 2008) in his letter to volunteers. However, this political strategy did not resonate with the idealists, who were outraged by the organizational identity breach.

Interestingly, the managerialists also attacked the key idealists accusing them of 'politicking' and 'power plays.' For instance, the motives of key figures were critically discussed in internal and external arenas: " [Chairperson 2] portrayed herself as the advocate of transparency for idealists - even though her main goal was to weaken the - in her view too dominantCEO 1." (Interview, top manager, 2008). Similarly, a managerialist board member complained: "It was terrible, UNICEF was destroyed. I thought it was violent. I blame the whistleblower and those who publicly turned against us ... I think that was clearly malicious." (Interview, board member, 2008). Various managerialist members of the organization also emphasized the damaging effects of the concerns which idealists had voiced internally and externally: "I wonder whether these individuals thought about the consequences of their actions? Donations are declining, we may even have to lay off people ... did they ever consider that?" (Observation, middle manager, mission development workshop, 2008).

\section{Political outcome: Reversal of balance in open conflict}

Reversal of balance. While Phase 1 saw a long period of managerialist dominance, Phase 2 meant a swift reversal of that power balance - at least in the discussion about the crisis. This was largely because of the political mobilization of the idealists and their focus on revealing the identity violations. Overall the wave of internal and external critique was overwhelming. Such criticism forced managerialists into a defensive position and helped idealists to gain influence. Thus, the managerialist-oriented top management was no longer in control of the organization. As one top manager suggests: “We are in the spotlight. We shouldn't have paid these commissions. It was completely wrong." (Interview, 2008, manager). In turn, idealists at 
all levels benefited from this organizational turmoil by gaining considerable influence: "The crisis changed many things. We finally brought the controversial topics to the table. It was chaotic but I enjoyed it." (Interview, 2008, idealist board member). Thus, the balance in organizational identity was reversed in the internal and external discussion - from the distorted development favoring the managerialists to a discussion where the idealist beliefs and values became dominant.

Open conflict. All this happened in an increasingly severe open conflict. Most visibly, idealist Chairperson 2 and managerialist CEO 1, each a key proponent of the respective perspective, clashed in public. A board member described the gravity of the conflict as follows: "One could trivialize the story to a conflict between individuals, but this is not the full picture. There was an organizational paralysis ... everyone seemed to be petrified. There was this inability to make a clear break quickly. The top management team was stunned by what was happening." (Interview, board member, 2008). A top manager confirms this: "We were all caught by surprise, nobody saw this conflict coming. There are disagreements about very fundamental aspects of our organization." (Interview, top manager, 2008).

Moreover, the conflict was seen as "out of control" and "an open battle," as a managerialist top management team member put it. The sense of chaos was well expressed by another top management team member: "Actually, the whole organization is turned inside out, and you do not know what's coming out." This open conflict culminated in the resignation of CEO 1, Chairperson 2, as well as the entire board in early 2008. This phase also saw the withdrawal of approval as a 'trusted charity' (Die Zeit, February 20, 2008). Although neither public prosecutor nor the consulting company KPMG hired to investigate the matter later found any legal substance for the allegations, neglect in formalizing business processes and decisions was noted (Der Spiegel, February 4, 2008). 


\section{Phase 3: Identity Reconstruction}

\section{Political strategies: Arguing for alternative identity constructions and forging a com-}

promise

The third phase was triggered by the pressure for reconciliation created by the crisis. Following the resignations of the key people, new board members and a new interim CEO 2 were elected. The idealists controlled the organization's agenda and were in a power position to demand an inclusive, transparent process of reviewing and reconstructing organizational identity. The managerialists, several of whom had just joined the organization, aimed at limiting the damage to the organization's reputation and to the decline in revenues by minimizing the organization's media exposure. In order to achieve these political aims, managerialists were willing to go along with idealists' calls. The two sides engaged in arguing for alternative identity constructions and ultimately forging a compromise shown in a new mission statement. Table 4 below offers an overview of these strategies.

Insert Table 4 about here

Arguing for alternative identity constructions. With the latent threat of fueling the public debate further, the idealists had political leverage over managerialists and thus pressed for identity reconstruction. Referring to the negative media coverage, one idealist top manager stated that these issues required attention: "The organization has not yet addressed these issues [identity breach and violations] openly. We need to do that." (Interview, top manager, 2008). Eventually, even managerialists acknowledged and agreed to the need for identity reconstruction. Pursuing the identity reconstruction internally would enable them to reduce the external exposure of the conflict and to declare the public conflict closed. As a managerialist board member stated: "We need to do some housecleaning. That's the way it should be. First we have to clean up and then we don't have to talk about it anymore." (Interview, top manager, 2008). 
In exploring the possibilities for reconstructing the organization's identity, both sides developed and offered alternative identity constructions. Idealists advanced a view of UNICEF as a child-rights activist to point to the organization's social impact as directly relevant for combating violations of children's rights worldwide. Here the principal goal was to maximize the social impact for children and other beneficiaries in the project countries. A board member summarized this compellingly: "Our mission is this: we are advocates for children." Furthermore, it assumed that children in the project countries were the organization's main stakeholder group; their welfare had to be enhanced through a benevolent, unidirectional support relationship, as underscored by a volunteer: "We want to help directly and immediately in Darfur!"

Closely related, the idealists also emphasized that UNICEF should become the authority on children's rights - operating with "scientific evidence" on the situation of children in Germany and beyond. Thus, the educational component of activism was stressed as UNICEF's key value. As one board member emphasized, "We aim at being the primary voice of children and their rights in Germany." Strongly impregnated with idealist values and beliefs, the activisteducator construction conceptualized UNICEF as a central player in the field of humanitarian and relief aid and in informing the public in developed countries.

In contrast, managerialists advocated and backed the fundraiser construction. Although somewhat stigmatized by the revelation of identity breach, managerialists continued to portray the need for raising donations as a "factual, objective necessity" of organizational survival. Consequently, the organization had to operate like a firm and manage its cost ratio (donations over costs) carefully. As a board member recalled, "Structurally, we should be operating like a firm." This organizational identity belief was based on the guiding ideal of efficiency and thus maximizing donations and managing costs effectively. According to the logic of this identity construction, UNICEF should strive for continuous growth in donations in a highly competitive German fundraising market to guarantee its long-term survival as an organization. 
Interestingly, the idealists and managerialists clashed over competing claims to occupy the moral high ground. From their respective perspectives, each side was using a variety of moral arguments to make their case. For instance, in a heated debate, an idealist stated that "any Euro not directly used for the kids is wasted." In turn, a managerialist argued - somewhat provocatively - whether "the kids actually would refuse a meal paid for by a fee-based donation?" (Observation, mission development workshop, 2008).

Forging a compromise on organizational identity. Since neither side had the ultimate power to force through their exclusive view, a political compromise on identity construction was needed. As a first step towards a compromise over organizational identity, both sides needed to negotiate their priorities. For instance, a managerialist board member suggested a balance of normative goals for the organization: "We should not be limited to a fundraising organization exclusively. That is not enough. In addition, we need to raise awareness of the plight of children worldwide." (Observation, board member, mission development workshop, 2009). In a way reciprocating this gesture for compromise, an idealist board member acknowledged the need for professional fundraising by admitting that "If we want to access new donors, and even if I personally dislike it, we need a truly professional fundraising practice." (Observation, board member, mission development workshop, 2008). Picking up on these leads, one managerialist top manager framed the need for a compromise on organizational identity as follows: "In revisiting our identity, we need to combine advocacy and fundraising. Our new mission statement should not focus on fundraising but rather on children's rights. In contrast, UNICEF USA is primarily, if not exclusively, a fundraising machine. We don't want to follow that path." Another key informant qualified the role of fundraising as an instrument rather than a normative goal: "Fundraising cannot be an end in itself. Fundraising serves as a means to an end, and that is to help children.... We have to change our mindset if we want to be less of a fundraising organization than we were in the past." 
This also included behind-the-scene political tactics used by both sides; for instance, in a crucial moment of a workshop, the idealist board members approached the managerialist Chairperson 3 over a coffee break and told him that the mission statement would win approval by the board much easier if the idealists got their "fair share" in the document. Similarly, an idealist top manager described her strategy as follows: "It is important to make a continuous effort to be noticed in a positive light. You cannot expect them [the board] to take notice themselves. We need to point out our [idealist] accomplishments and remind people about the important work we do in schools.” (Observation, mission development workshop, 2009).

A draft of the revised mission statement represents this compromise between managerialist and idealist points of view (see the Online Appendix for an illustration of the compromises made in the board's discussion). Overall, the board took a rather idealist stance with respect to purpose and the key role of the volunteers but also made sure to include professionalism, decision-making, and innovation in the new mission. Furthermore, the board's decisions provided the basis for producing an official version of the mission statement (see the Online Appendix for the final version). Board members, however, clearly understood that this identity construction was indeed a compromise: "All these voices will be heard but in the end, we [the board] will make the decision ... Not everybody will approve of it 100\%." (Interview, board member, 2009).

\section{Political effects: Restoration of balance in orchestrated consensus}

Restoration of balance. While Phase 2 saw the reversal of power balance with the idealists holding the upper hand politically, Phase 3 led to a restoration of that balance. This restoration was built on both sides arguing for alternative constructions. The idealists had gained a strong power position to voice their concerns as a result of Phase 2, but the managerialists, many of them new members, had also found new ways of making their views heard: "The most important aspect of this process is to bring those different perspectives together. It's important 
to gain mutual understanding for each perspective - to understand why others see things differently. To me that is way more important than the actual content of the mission statement itself." (Interview, managerialist top manager, 2009). Thus, the discussion about organizational identity was more balanced from the start, and - as described above - both sides also succeeded in making persuasive and convincing arguments to promote their views. This offered a rich basis for the compromise.

Orchestrated consensus. The focus on forging the compromise provided both sides an opportunity to engage in a constructive dialogue over identity. In particular, the mission review process allowed for identity violations to be expressed and explained in a constructive setting. A top management team member explained this as follows: "All the issues are more obvious now. There were so many conflicts here and so many people felt ignored. We've now worked this out, clearly and quickly." (Interview, managerialist top manager, 2009).

The key managerialists and idealists - the new dominant coalition - gathered behind the orchestrated compromise. The board and management saw the process as an effective vehicle for a swift conflict resolution. Moreover, the top management team and board members emphasized the positive aspect of the process in producing the new organizational identity: "Now, there is more openness, more clarity towards each other. Now we can tackle conflicts more openly." (Interview, top manager, 2009). Thus, phase 3 concluded with a compromise on organizational identity as crystallized in the new mission statement.

\section{Phase 4: Enactment of the Reconstructed Identity \\ Political strategies: Enforcing and maintaining the compromise}

The fourth phase was triggered by an urge to conclude the reconstruction and to move on. It focused on enacting the reconstructed identity as spearheaded by the new mission statement. Thus, the new dominant coalition consisting of both managerialists and idealists enforced the compromise through visible frontstage activities in various parts of the organization. This 
was complemented by backstage deliberations in arenas such as management retreats to maintain the compromise. Table 5 provides an overview of these strategies.

Insert Table 5 about here

Enforcing the compromise on organizational identity. As a first prerequisite of this political strategy, the raw version was processed by the communications and marketing team and resulted in a polished version - "ready for consumption" by internal and external stakeholders. This allowed managerialists in key positions to make sure that their key beliefs and values would be emphasized. Based on this artefact, top management initiated and organized several visible activities to spread and contextualize the compromise. As a top manager summarizes, "Sub-objectives have been developed, for example, implementation of the mission statement in all organizational units, introduction of an annual staff appraisal, development of a common understanding of leadership and culture. And then it came down to measurement criteria." (Observation, top manager, strategy workshop, 2012).

Further efforts to enforce the compromise included regular Friday staff gatherings in the main hall at HQ to exemplify and "apply the mission to explore and understand daily challenges and decisions." "Applying the mission" in such a public way not only spread the mission but also promoted it through repetition. Furthermore, key aspects of the new mission were integrated with the annual staff appraisal protocol, e.g. questions specifically asking staff whether and how they had contributed to a specific sub-item of the mission. In concert, these frontstage enforcement activities rendered the mission the new behavioral point of reference individually and in collective settings such as staff gatherings. In a related promotional move, an enlarged artefact of the mission statement was distributed throughout the entire organization - to HQ and regional volunteer offices alike. This artefact of the mission statement equally sought to spread the new "ideological standard." A related staff survey reported $80 \%$ approval - this was another component in enforcement of the compromise on identity. 
Politically, both sides seemed to benefit from this enforcement strategy. While the idealists had their normative values anchored, affirmed and spread, the managerialists were able to demonstrate control over the overall direction and to move on. As a top manager stated, "Now, we got our priorities straight. On the basis of this process we can now move on and start planning our strategy.” (Observation, top manager, strategy workshop, 2011).

Maintaining the compromise. However, a second political strategy was necessary to sustain the compromise. Both sides were well aware of the ambivalence of the compromise reached, as a top manager observed: "It will always be a challenge to keep the balance between our commercial logic and our social side ... I believe it will always be difficult to communicate the economic logic in our organization. " (Observation, top manager, strategy workshop, 2013). This ambivalence, however, was acknowledged and explored mainly in the backstage setting and at the top management and board level. Until very recently, it was still present in the organization as a top manager explains: "We have two, if not three, purposes side by side. One is to raise as much funds as possible and on the other hand we want to improve the situation of children. We fight for children's rights in Germany and worldwide, but we also inform - we encourage people to get involved. So fundraising is only one of several goals of this organization." (Interview, top manager, 2017).

Maintenance work in terms of reinterpreting and reconfirming the compromise also took place in top management retreats and workshops. Consecutive annual strategy retreats 20102012, the managerialists and idealists in the top management team realized that the compromise had not done away with the inherent tensions of the organization. Although the top management team was satisfied with the "mission statement as a broad identity construction" for responding to breach, they nevertheless expressed the "need for more clarity, direction, and guidance" of the organization's identity. While a strategy retreat in 2010 focused very much on hands-on annual planning and budgeting, the strategy retreat in 2011 revealed the need to "explore what 
we actually stand for" (CEO 4). As an idealist top manager proposed, "should we foreground either our content expertise or the idea of a movement for children?" This view was countered by a managerialist top manager as follows: "Where is the financial return if we choose to become a fully-fledged movement for children? Can we afford this? Does such a choice increase our impact? What do we gain?" (Observation, strategy workshop, 2011). Thus, both parties acknowledged each other's views and could maintain the compromise - as crystallized in the mission statement and the reproduced in the new strategy documents.

\section{Political effects: Effectuation of balance and sustained consensus}

Effectuation of balance. Enforcing and maintaining the compromise helped to make sure that the hard-won balance in organizational identity would prevail. As a top manager explained, the organizational identity debate had been largely settled: "We have moved on. We got over it [debate between managerialists and idealists]. This is good news. Hardly anyone talks about 'the crisis' anymore." (Observation, top manager, volunteer management workshop, 2013). While enforcing the compromise was necessary to root the new balanced organizational identity in the organization, maintaining the compromise was also needed to keep an eye on the power balance: "We need to hold the organization together [in balance] despite all differences. That requires leadership, leadership, leadership." (Interview, managerialist top manager, 2010).

Sustained consensus. Thus, maintenance was the key for sustaining the consensus. As an idealist top manager put it in their 2011 retreat: "Whether we are an expert organization or a movement for children is not a decision we can make. We are and will be inherently both. At best, we can settle on where to put the emphasis." Others were under no illusion that no mission statement, no matter how well-crafted, would do away with the inherent tensions. As a top manager acknowledged, "we keep having discussions about our fundraising tools with the volunteers" as "fee-based fundraising remains a most sensitive topic. We know it, and we will have 
to keep it in mind." On the same note, an idealist top manager explained that she also needs to tread carefully in 2017 due to the hidden tensions over identity in her team: "We are still not used to conflict or open debate. UNICEF continues to operate in a culture of consensus. We do not express disagreement openly. I see that clearly in my team. I have to be really careful about what I say." (Interview, top manager, 2017). Thus, although the focus was on consensus, one could again detect elements of underlying tensions.

\section{DISCUSSION}

Our analysis advances prior research on organizational identity breach and reconstruction by offering a sorely needed political perspective that elucidates the political dynamics and strategies involved. By focusing on the hybrid setting, our analysis also has specific implications for research on hybrid identities. Furthermore, it adds to the political analysis of organizational identity more generally and thus paves the way for new political analyses of organizational identity.

\section{Uncovering the Political Dynamics of Organizational Identity Breach and Reconstruction}

Although we have seen increasing interest in organizational identity tensions (Ashforth \& Reingen, 2014; Corley \& Gioia, 2004; Gioia et al., 2010; Kreiner et al., 2015; Nag et al., 2007) and identity reconstruction (Ravasi \& Schultz, 2006; Schultz \& Hernes, 2013), our understanding of the political dynamics of organizational identity breach and reconstruction remains incomplete. Thus, the key contribution of our paper is that it advances our understanding of organizational identity breach and reconstruction as political processes by revealing the underlying political dynamics and strategies involved. In particular, we have outlined a process model that elucidates the political dynamics and strategies unfolding through four phases build-up of identity tensions, revelation of identity breach, identity reconstruction, and enactment of the reconstructed identity - as well as the triggers explaining shifts between the phases 
(see Figure 3). Although the four phases may be seen as sequences of identity breach and reconstruction process, it should be noted that they also might involve recursive loops and possibly overlap temporally in other contexts. Our model is therefore cyclical rather than linear. We also maintain that in many cases these phases may not be as salient as in our revelatory UNICEF case.

The conventional view would be to see the UNICEF case as an example of a 'broken' identity, which is consequently 'repaired,' but such a view would be limited because it fails to capture the underlying political processes and strategies at play. What our perspective shows instead is that any breach or reconstruction involves political struggles over meaning where the views of the dominant coalition constitute the basis of consensus or conflict over organizational identity. As our analysis vividly illustrates, a key dimension in this struggle is the balance of power as reflected in organizational identity. In essence, parties pursue their own interests and need to see their own identity beliefs reflected in what they perceive the key activities of the organization. This balance is at times, however, distorted, which is the key issue underlying breach and the key driver of its restoration (as shown in the horizontal arrow denoting risk of developing a one-sided identity and restoration of balance in the model figure).

The other key dimension is consensus/conflict. In this view, there is usually underlying conflict, even if it is often suppressed or disguised. What makes this phenomenon ontologically complex - and thus also methodologically challenging to capture - is that most often people are not aware or at least do not focus attention on the underlying tension or conflict. As our case demonstrates, breach and reconstruction are the phases where this does take place - conflict is surfaced and consensus is deliberately reconstructed (as shown by the vertical arrows denoting surfacing and hiding conflict in the model figure).

This view, although different from mainstream research on organizational identity, can be directly linked with existing research on identity tensions. More specifically, our analysis 
adds to previous research on tensions (Elsbach \& Kramer, 1996; Ravasi \& Schultz, 2006) and reactions to breach (Glynn, 2000; Golden-Biddle \& Rao, 1997) by offering an empiricallygrounded process model explaining the underlying political dynamics. Furthermore, our analysis takes a step further in spelling out the radical implications of consensus and conflict. In particular, underlying tensions may erupt in breaches where a disguised conflict turns into an open one. Thus, what appears to be a widely recognized identity breach is in fact a politically motivated construction to shape and ultimately dominate the discussion. In such processes, especially if they involve the media and are framed as crises, the views of specific actors win and others may lose.

Similarly, identity reconstruction may in cases like ours be based on compromise, although such compromise is still based on orchestration by the dominant coalition. By highlighting this political side of identity reconstruction, our analysis extends prior research on identity re-examination (Ravasi \& Schultz, 2006), identity reconstruction (Schultz \& Hernes, 2013), and identity resurrection (Howard-Grenville et al., 2013). As our case shows, identity reconstruction can involve a multiplicity of views, but has to ultimate resonate with the views of those in power. What is central to our model is that it highlights the antecedents of reconstruction in breach. This view enlarges our understanding of reconstruction to include threats, crises, or scandals that have conventionally been seen as problems - not the steps preceding identity reconstruction or even those needed therein. Thus, we advance the idea that conflict is quintessential for breaking up a violated identity and thus also for subsequent reconstruction. Moreover, as the feedback loop in our model indicates, such consensus may over time also become one-sided and constitute what others have called drift (Golant, Sillince, Harvey, \& Maclean, 2015; Ravasi \& Phillips, 2011), thus potentially leading again to the build-up of identity tensions. 
A key part of our model is that it elucidates the political strategies used by the actors involved as well as their intended and unintended consequences. Identifying and elaborating on these strategies thus helps explain what the actors can do to establish and/or deal with an identity breach and reconstruction. In the first phase, normalizing and masking are particularly interesting strategies that allow the dominant coalition to reinforce specific identity beliefs and suppress alternative views. Normalizing is indeed a key means to exercise power in a way that privileges one side's identity beliefs while ignoring those of the other side - effectively distorting the organizational power balance in favor of managerialists and marginalizing the idealists in our case. Masking of controversial actions may help prevent negative reactions for a period of time, but when such actions are revealed and framed as violations, the result can be as dramatic as in our case. Thus, these strategies were key reasons for the build-up of tensions leading to revelation of breach in the second phase. In this phase, the political forces turn as those who have experienced violations focus on revealing identity violations, which may be countered by those defending the previous beliefs and values. The revelation of identity violations is thus the key strategy for those who want to promote fundamental change. In a case such as ours a revelation of this kind can be based on an authentic sense of violations, but it may also require purposeful framing and swift political action to arouse critical discussion in internal and external arenas. The other side, in our case the managerialists, may in turn try to counter this momentum with defensive strategies, but as our case vividly shows they may not be enough to change the political dynamics. Thus, actors such as the idealists in our case may succeed in gaining sufficient momentum to reverse the power configuration.

In the third phase, identity reconstruction may in cases such as ours be triggered by arguing for alternative identity constructions and forging a compromise on identity. Arguing for one's own identity beliefs is a key strategy, which is needed to make one's voice heard and to 
try to influence others. In UNICEF Germany, the parties engaged in a rather constructive discussion, which might not be the case in other settings. Forging a compromise can in turn be seen as a joint strategy involving both sides, thus illuminating the restoration of the power balance in orchestrated consensus. Finally, in enactment of the reconstructed identity, the key strategies - followed by both sides as long as they believe in the compromise - include enforcing and maintaining the compromise. As our case illustrates, such strategies are needed in the front and backstage of the organization to make sure that the new identity beliefs are spread, reinforced, and indeed continue to be followed.

Our analysis clearly shows how the strategies operate at more surface or hidden levels of power (Clegg, 1989; Foucault, 1980; Lukes, 1974). In particular, the strategies of the first phase - normalizing and masking - shape the boundaries of the legitimate organizational identity discourse and mostly operate at a hidden rather than surface level. The strategies of the second phase - revealing and defending - are in turn clear examples of straightforward politicking, thus representing the surface level of power and overt political activity. The strategies in third phase - arguing and forging a compromise - are also mostly overt strategies that show an intention to reach consensus, orchestrated by the new dominant coalition. Finally, the strategies of the fourth phase - enforcing and maintaining - are in part purposive efforts but also operate at a level that likely passes unnoticed for most organizational members.

\section{Implications for Research on Hybrid Identities}

Our model specifically highlights the politics of identity breach and reconstruction in a hybrid setting (Ashforth \& Reingen, 2014; Foreman \& Whetten, 2002; Golden-Biddle \& Rao, 1997; Smith \& Besharov, 2019). Thus, our analysis extends research on hybrid organizations (Ashforth \& Reingen, 2014; Foreman \& Whetten, 2002; Golden-Biddle \& Rao, 1997). In this kind of setting, the tensions and consequent conflict and consensus are often particularly salient - maybe even ever-present. Thus, breach and reconstruction are likely to be central phenomena 
in and around these kinds of organizations - especially if and when there are actors such as volunteers who may easily be sidelined in the organization's activities.

Our analysis illuminates how the processes of organizational identity breach and reconstruction revolve around a balance of power in hybrid organizations. While prior studies offer evidence of the central role of balance of power between the key actors (Ashforth \& Reingen, 2014; Besharov, 2014; Foreman \& Whetten, 2002; Gümüsay et al., 2019; Smith \& Besharov, 2019), our analysis makes the struggles explicit in the context of breach and reconstruction. In particular, our UNICEF case helps to show that the nature of the struggles is distinctively different in the four phases identified. Furthermore, our analysis reverses the implicit premise of most studies, namely that a balance of power in a consensus on identity is the normal state of affairs in hybrid organizations. Our analysis rather promotes a dialectical view analogous to Kreiner et al (2015), where the parties engage in ongoing struggles where consensus may indeed be achieved at times, but it is likely to be partial and always reflect the views of the dominant coalition. Moreover, the nature of consensus and conflict also take different forms and are often at least partly disguised or hidden - until the tensions build-up so high that political action is needed to reveal the identity breach.

What is special in our case - compared to most other studies of hybrid identities (Ashforth \& Reingen, 2014; Besharov \& Smith, 2014; Foreman \& Whetten, 2002; GoldenBiddle \& Rao, 1997) - is that is shows how the idealists may at times succeed in restoring the power balance to their favor. In most hybrid organizations - including in our case - managerialists occupy critical managerial positions and thus control important resources, financial or otherwise. Our study thus provides a rare example of the idealists, if not 'winning,' then at least reaching a favorable balance in the new reconstructed identity. Thus, our case can be seen as an encouraging example of how whistleblowing (Kenny et al., 2020) or similar actions may help to mobilize actors to change the state-of-affairs. Interestingly, in our case the effect 
seemed to be long-lasting, even if one can detect new risks of tilting towards a one-sided identity at the end of our observation period.

\section{Furthering the Political Perspective in Organizational Identity Research}

By outlining a political view on organizational identity breach and reconstruction, our analysis has also broader implications for organizational identity research (Bednar, Galvin, Ashforth, \& Hafermalz, 2019; Gioia et al., 2013b; Kreiner et al., 2015). In a nutshell, it shows a need to complement the predominant cognitive and cultural perspectives on organizational identity with a view that acknowledges the role of power and politics in organizational identity construction. Although scholars have already pointed to sociopolitical processes and practices (Glynn, 2000; Kenny et al., 2016; Rodrigues \& Child, 2008), these aspects of organizational identity still remain undertheorized and underexplored.

As our analysis shows, to dig deeper into the dynamics that drive radical forms of organizational identity change such as breach, it would be paramount to elucidate the political processes and strategies at play. By suggesting a view of organizational identities as constructions involving both consensus and conflict, by seeing breach and reconstruction as phases in longerterm political processes involving struggles between different coalitions, and by identifying and elaborating on concrete political strategies used, our analysis offers an example of taking power and politics seriously in organizational identity research. Thus, we believe that with due caution this empirically grounded framework can also be used in other settings to tease out the political dynamics and strategies at play.

Thus, the political dynamics in our model reveal a struggle that easily passes unnoticed in more conventional analysis of organizational identity change. It can be seen as a novel type of dialectic complementing findings in previous research adopting a dialectical view on organizational identity (Kreiner et al., 2015). We can best observe the political forces at play precisely in moments of breach and reconstruction - as highlighted in revealing cases such as ours. 
However, one could expect similar political dynamics to play out in other contexts, too. This is the key takeaway from this study, which suggests paying close attention to the political forces, struggles, and strategies involved in organizational identity change or identity work more generally. Thus, rather than considering organizational identity an apolitical reflection of the beliefs and values of members, we would do better to view organizational identity as an effortful political accomplishment that may at some point be challenged and even turned around. Indeed, based on our analysis, the key issue is not only how politics may 'disturb' the prevailing organizational stability, but rather how political action may be needed to surface the issues and to restore a consensus - even if always based on the views of a dominant coalition.

\section{Limitations and Future Research}

Although our model is based on a revealing case, we argue that with due caution it can be used to make sense of the dynamics of organizational identity breach and reconstruction. Nevertheless, its boundary conditions and limitations should be taken seriously. In particular, our case has idiosyncratic features that may not be found in other contexts. Thus, it would be important to study organizational identity breach in settings other than hybrid organizations or the German context. For instance, such analysis could focus on how organizational identity breach and reconstruction unfold in organizations with other goal sets, such as profit-orientation or public value generation. We have focused on intra-organizational considerations of organizational identity breach and subsequent reconstruction work. However, much of this work is also conducted outside organizational boundaries, for example by the media. It would thus be interesting to explore identity breach and reconstruction from the perspective of external constituencies. For example, future studies could focus on how external stakeholders perceive and react to organizational identity breach and the role they might play in its reconstruction. It would also be fruitful to compare how the processes of breach and reconstruction may unfold in different parts of organizations. In our case, volunteers have played a key role; it would be 
important to compare it with other cases without such stakeholders. Thus, future studies could focus on how people at different hierarchical levels experience and cope with organizational identity breach and reconstruction or whether different functional and professional backgrounds make a difference. In particular, it would be useful to identify a comparative case design in which an entire sector, industry or strategic group exposed to organizational identity breach.

While we have identified and elaborated on political strategies that are likely to play a key role in these processes, future studies could go deeper and also explore new ones. Future research could for instance explore the processes of masking and silencing in more detail to understand the 'darker side' of organizational identity construction and reconstruction. It would be especially interesting to examine other strategies that may contribute to the build-up of identity tensions and a distortion of a power balance. In addition, the deliberate work done in framing to construct identity breach is a topic that warrant close attention in future work. Since organizational identity breach refers to perceived violation of organizational identity breach, future studies might explore in more detail such perceptions at the individual and group level and their implications for action or inaction. Future studies could also dig deeper into specific aspects of identity reconstruction such as the politics involved in reinterpreting and connecting of past and future identities (Schultz \& Hernes, 2013) or in orchestrating memorable experiences and eliciting emotions in community members (Howard-Grenville et al., 2013). It would also be illuminating to examine more specifically how to deal with particular organizational identity violations. Furthermore, it would be interesting to zoom in on the discursive or rhetorical aspects of identity reconstruction, thus highlighting the more or less deliberate use of language to pursue one's own interests or values. Such analysis could also focus on the discursive micro-level and use for instance methods of critical discourse analysis to highlight the role of power and ideology in meetings, conversations or texts dealing with identity beliefs and claims. 
Finally, as our analysis illustrates, identity construction and reconstruction involve conflict and resistance, and this 'darker side' of organizational identity warrants special attention in future research, not only in the context of identity breach or reconstruction. 


\section{REFERENCES}

Albert, S. \& Whetten, D. A. 1985. Organizational identity. In L. L. Cummings \& B. M. Staw (Eds.), Research in Organizational Behavior, vol. 7: 263-295. Greenwich, Conn.: JAI Press.

Alvesson, M. \& Willmott, H. 2002. Identity regulation as organizational control: Producing the appropriate individual. Journal of Management Studies, 39(5): 619-644.

Ashforth, B. E. \& Reingen, P. H. 2014. Functions of dysfunction: Managing the dynamics of an organizational duality in a natural food cooperative. Administrative Science Quarterly, 59(3): 474-516.

Bankins, S. 2015. A Process Perspective on psychological contract change: Making sense of, and repairing, psychological contract breach and violation through employee Coping Actions. Journal of Organizational Behavior, 36(8): 1071-1095.

Bednar, J. S., Galvin, B. M., Ashforth, B. E., \& Hafermalz, E. 2019. Putting identification in motion: A dynamic view of organizational identification. Organization Science, forthcoming.

Besharov, M. L. 2014. The relational ecology of identification: How organizational identification emerges when individuals hold divergent values. Academy of Management Journal, 57(5): 1485-1512.

Besharov, M. L. \& Smith, W. K. 2014. Multiple institutional logics in organizations: Explaining their varied nature and implications. Academy of Management Review, 39(3): 364-381.

Brickson, S. L. 2007. Organizational identity orientation: The genesis of the role of the firm and distinct forms of social value. Academy of Management Review, 32(3): 864-888.

Brown, A. 2020. Identities in organizations. In A. Brown (Ed.), The Oxford Handbook of Identities in Organizations. Oxford: Oxford University Press.

Brown, A. 2015. Identities and identity work in organizations. International Journal of Management Reviews, 17(1): 20-40.

Brown, A. D., Kornberger, M., Clegg, S. R., \& Carter, C. 2010. 'Invisible walls' and 'silent hierarchies': A case study of power relations in an architecture firm. Human Relations, 63(4): 525-549.

Clark, S. M., Gioia, D. A., Ketchen, D. J., \& Thomas, J. B. 2010. Transitional identity as a facilitator of organizational identity change during a merger. Administrative Science Quarterly, 55(3): 397-438.

Clegg, S. 1989. Frameworks of Power. London: Sage Publications.

Clegg, S. R., Courpasson, D., \& Phillips, N. 2006. Power and Organizations. London: Sage Publication.

Corley, K. G. \& Gioia, D. A. 2004. Identity ambiguity and change in the wake of a corporate spin-off Administrative Science Quarterly, 49(2): 173-208.

Coyle-Shapiro, J. A.-M., Pereira Costa, S., Doden, W., \& Chang, C. 2019. Psychological contracts: Past, present, and future. Annual Review of Organizational Psychology and Organizational Behavior, 6: 145-169.

Dulac, T., Coyle-Shapiro, J. A.-M., Henderson, D. J., \& Wayne, S. J. 2008. Not all Responses to breach are the same: The interconnection of social exchange and psychological contract processes in organizations. Academy of Management Journal, 51(6): 10791098.

Elsbach, K. D. \& Kramer, R. M. 1996. Members' responses to organizational identity threats: Encountering and countering the Business Week rankings. Administrative Science Quarterly, 41(3): 442-476.

Feldman, M. S. 1995. Strategies for Interpreting Qualitative Data. Thousand Oaks: Sage Publications. 
Fleming, P. \& Spicer, A. 2014. Power in management and organization science. The Academy of Management Annals, 8(1): 237-298.

Foreman, P. \& Whetten, D. A. 2002. Members' identification with multiple-identity organizations. Organization Science, 13(6): 618-635.

Foucault, M. 1980. Power/Knowledge: Selected Interviews and Other Writings, 1972-1977. New York: Pantheon Books.

Garfinkel, H. 1967. Studies in Ethnomethodology. New Jersey: Prentice-Hall.

Gioia, D. A., Price, K. N., Hamilton, A. L., \& Thomas, J. B. 2010. Forging an identity: An insider-outsider study of processes involved in the formation of organizational identity. Administrative Science Quarterly, 55(1): 1-46.

Gioia, D. A., Corley, K. G., \& Hamilton, A. L. 2013. Seeking qualitative rigor in inductive research: Notes on the Gioia methodology. Organizational Research Methods, 16(1): $15-31$.

Gioia, D. A., Patvardhan, S. D., Hamilton, A. L., \& Corley, K. G. 2013. Organizational identity formation and change. The Academy of Management Annals, 7(1): 123-192.

Glynn, M. A. 2000. When cymbals become symbols: Conflict over organizational identity within a symphony orchestra. Organization Science, 11(3): 285-298.

Golant, B. D., Sillince, J. A., Harvey, C., \& Maclean, M. 2015. Rhetoric of stability and change: The organizational identity work of institutional leadership. Human Relations, 68(4): 607-631.

Golden-Biddle, K. \& Rao, H. 1997. Breaches in the boardroom: Organizational identity and conflicts of commitment in a nonprofit organization. Organization Science, 8(6): 593611.

Gümüsay, A. A., Smets, M., \& Morris, T. 2019. 'God at work': Engaging central and incompatible institutional logics through elastic hybridity. Academy of Management Journal, online first.

Howard-Grenville, J., Metzger, M. L., \& Meyer, A. D. 2013. Rekindling the flame: Processes of identity resurrection. Academy of Management Journal, 56(1): 113-136.

Kenny, K., Whittle, A., \& Willmott, H. 2016. Organizational identity: The significance of power and politics. In M. G. Pratt, M. Schultz, B. E. Ashforth, \& D. Ravasi (Eds.), Oxford Handbook of Organizational Identity: 140-159. Oxford: Oxford University Press.

Kenny, K., Fotaki, M., \& Vandekerckhove, W. 2020. Whistleblower subjectivities: Organization and passionate Attachment. Organization Studies, 41(3): 323-343.

Ketokivi, M. \& Mantere, S. 2010. Two strategies for inductive reasoning in organizational research. Academy of Management Review, 35(2): 315-333.

Kreiner, G. E., Hollensbe, E., Sheep, M. L., Smith, B. R., \& Kataria, N. 2015. Elasticity and the dialectic tensions of organizational identity: How can we hold together while we are pulling apart? Academy of Management Journal, 58(4): 981-1011.

Langley, A. \& Abdallah, C. 2011. Templates and turns in qualitative studies of strategy and management. In D. D. Bergh \& D. J. Ketchen (Eds.), Building Methodological Bridges, Vol. 6: 201-235. Bingley, UK: Emerald Group Publishing Limited.

Langley, A. \& Klag, M. 2019. Being where? Navigating the involvement paradox in qualitative research accounts. Organizational Research Methods, 22(2): 515-538.

Locke, K., Golden-Biddle, K., \& Feldman, M. S. 2008. Making doubt generative: Rethinking the role of doubt in the research process. Organization Science, 19(6): 907-918.

Lukes, S. M. 1974. Power: A Radical View. London: Macmillan.

Lüscher, L. S. \& Lewis, M. W. 2008. Organizational change and managerial sensemaking: Working through paradox. Academy of Management Journal, 51(2): 221-240. 
Nag, R., Corley, K. G., \& Gioia, D. A. 2007. The intersection of organizational identity, knowledge, and practice: Attempting strategic change via knowledge grafting. Academy of Management Journal, 50(4): 821-847.

OHCHR. 2019. Convention on the Rights of the Child: https://www.ohchr.org/en/professionalinterest/pages/crc.aspx

Petriglieri, J. L. \& Devine, B. A. 2016. Mobilizing organizational action against identity threats. In M. G. Pratt, M. Schultz, B. E. Ashforth, \& D. Ravasi (Eds.), The Oxford Handbook of Organizational Identity: 239-256.

Pfeffer, J. \& Salancik, G. R. 1974. Organizational decision making as a political process: The case of a university budget. Administrative Science Quarterly, 19(2): 135-151.

Pratt, M. G., Schultz, M., Ashforth, B. E., \& Ravasi, D. 2016. Organizational identity: Mapping where we have been, where we are, and where we go. In M. G. Pratt, M. Schultz, B. E. Ashforth, \& D. Ravasi (Eds.), The Oxford Handbook of Organizational Identity. Oxford: Oxford University Press.

Ravasi, D. \& Schultz, M. 2006. Responding to organizational identity threats: Exploring the role of organizational culture. Academy of Management Journal, 49(3): 433-458.

Ravasi, D. \& Phillips, N. 2011. Strategies of alignment: Organizational identity management and strategic change at Bang \& Olufsen. Strategic Organization, 9(2): 103-135.

Ravasi, D., Rindova, V., \& Stigliani, I. 2019. The stuff of legend: History, memory, and the temporality of organizational identity construction. Academy of Management Journal, 62(5): 1523-1555.

Rodrigues, S. \& Child, J. 2008. The development of corporate identity: A political perspective. Journal of Management Studies, 45(5): 885-911.

Schein, E. H. 1995. Process consultation, action research and clinical inquiry: are they the same?. Journal of Managerial Psychology, 10(6): 14-19.

Schultz, M. \& Hernes, T. 2013. A temporal perspective on organizational identity. Organization Science, 24(1): 1-21.

Smith, W. K. \& Besharov, M. L. 2019. Bowing before dual gods: How structured flexibility sustains organizational hybridity. Administrative Science Quarterly, 64(1): 1-44.

Spendenrat, D. 2009. Bilanz des Helfens 2009: https://www.spendenrat.de/2009/10/08/bilanz-des-helfens-2009/ [Accessed 14 May 2019].

Strauss, A. \& Corbin, J. 1998. Basics of Qualitative Research. Techniques and Procedures for Developing Grounded Theory. Thousands Oaks, London, New Delhi: Sage Publications.

Sveningsson, S. \& Alvesson, M. 2003. Managing managerial identities: Organizational fragmentation, discourse and identity struggle. Human Relations, 56(10): 1163-1193.

Tripsas, M. 2009. Technology, identity, and inertia through the lens of "The digital photography company". Organization Science, 20(2): 441-460.

UNICEF. 2009. UNICEF Annual Report 2009: https://www.unicef.de/informieren/ueberuns/transparenz-bei-unicef/geschaeftsbericht [Accessed 17 Mar. 2019].

UNICEF. 2019. UNICEF National Committees: https://www.unicef.org/unicef-nationalcommittees [Accessed 13 Mar. 2019].

Van Maanen, J., Sørensen, J. B., \& Mitchell, T. R. 2007. The interplay between theory and method. Academy of Management Review, 32(4): 1145-1154.

Willmott, H. 2013. Reflections on the darker side of conventional power analytics. Academy of Management Perspectives, 27(4): 281-286.

Wodak, R., de Cillia, R., Reisigl, M., Liebhart, K., Hirsch, A., Mitten, R., \& Unger, J. W. 1999. The Discursive Construction of National Identity. Edinburgh: EUP. 
Table 1: Empirical Material

\begin{tabular}{|c|c|c|}
\hline & Types of material & Use in analysis \\
\hline Observation & $\begin{array}{ll} & \text { Mission development workshops (8) 2008-2009 } \\
\text { - } & \text { Board meetings (6) 2009-2017 } \\
\text { - } & \text { Strategy retreats (10) 2009-2012, } 2017 \\
\text { - } & \text { Other workshops and meetings (3) 2010-2013 }\end{array}$ & $\begin{array}{l}\text { - Analysis of themes and patterns of identity dynamics over time } \\
\text { - Tracking of identity beliefs and constructions and their expres- } \\
\text { sions in various contexts } \\
\text { - Analysis of tensions and political dynamics as they played out } \\
\text { in various arenas } \\
\text { - } \quad \text { Focus on political strategies }\end{array}$ \\
\hline Interviews & $\begin{array}{ll}\text { - } & \text { Board members (new and old, including chairpersons) (11) } \\
\text { - } & \text { Top managers (old and new, including CEOs) (23) } \\
\text { - } & \text { Middle managers (10) } \\
\text { - } & \text { Informal conversations with a number of organizational mem- } \\
\text { bers }\end{array}$ & $\begin{array}{l}\text { - Analysis of themes and patterns of identity dynamics over time } \\
\text { with a focus on identity beliefs and experiences of violations } \\
\text { thereof } \\
\text { - } \quad \text { Reconstruction of tensions and political dynamics including } \\
\text { reasons for political action } \\
\text { - Analysis of political strategies and reasons for employing them }\end{array}$ \\
\hline Documents & $\begin{array}{l}\text { - Agendas, minutes, and documents used in workshops, board and } \\
\text { other high-level meetings (20) 2007-2019 } \\
\text { - Internal presentations and reports on strategic planning, market- } \\
\text { ing, communication, and volunteer involvement (20) 2007-2017 } \\
\text { - Strategic plans and their drafts (10) 2007-2017 } \\
\text { - Annual reports (10) 2007-2017 }\end{array}$ & $\begin{array}{l}\text { - } \\
\text { - Analysis of themes and patterns of identity change as expressed in } \\
\text { documents } \\
\text { - Tracking agendas and minutes of meetings for evidence of identity } \\
\text { tensions and divides } \\
\text { - Analysis of drafts and representations of identity constructions es- } \\
\text { pecially in identity reconstruction and enactment of reconstructed } \\
\text { identity } \\
\text { - Focus on how the new mission statement was created and commu- } \\
\text { nicated } \\
\text { Getting insights into official communication in the context of iden- } \\
\text { tity breach and reconstruction }\end{array}$ \\
\hline Media material & $\begin{array}{l}\text { - Newspaper articles (selection of articles in which members ex- } \\
\text { press their view on UNICEFs identity and violations thereof) } \\
\text { (50 out of a total of more than } 250)\end{array}$ & $\begin{array}{l}\text { - } \\
\text { - } \\
\text { - Analysis of the role of media in political dynamics } \\
\text { Analysis how media was used to express identity violations and to } \\
\text { constitute an overall sense of identity breach or to defend prevail- } \\
\text { ing beliefs and practices }\end{array}$ \\
\hline
\end{tabular}


Table 2: Build-Up of Identity Tensions: Examples of Empirical Material

\begin{tabular}{|c|c|c|}
\hline $\begin{array}{l}\text { Aggre- } \\
\text { gate }\end{array}$ & $\begin{array}{l}\text { Second order } \\
\text { themes }\end{array}$ & Examples of empirical material \\
\hline \multirow{2}{*}{$\begin{array}{l}\text { Political } \\
\text { strategies }\end{array}$} & $\begin{array}{l}\text { Normalizing } \\
\text { specific iden- } \\
\text { tity beliefs }\end{array}$ & $\begin{array}{l}\text { - Managerialists promote their identity beliefs in internal and external arenas: } \\
\text { "[Referring to pre-crisis phase] UNICEF was always the most efficient of all } 40 \text { country offices. I am talking about the ratio between income } \\
\text { and expenditure. That is our key indicator of quality. ... We may be more than just a fundraising organization but I personally do not care } \\
\text { about the child rights lobbying campaigns in Germany." (interview, board member, 2010] } \\
\text { "I joined UNICEF as a business person [5 years prior to the crisis]. My first impression was this is the same as any other company. I could } \\
\text { have joined Proctor\&Gamble instead. It was only about fundraising, always." (interview, intern, 2019) } \\
\text { - Board does not question managerialist identity beliefs or new business practices: } \\
\text { "We did not act as a supervisory body [questioning the managerialist beliefs]." (interview, board member, 2008) } \\
\text { "The board did not influence anything; there were not an active controlling body. Many were surprisingly ill-informed and had little to no } \\
\text { insights." (interview, top manager, 2008) }\end{array}$ \\
\hline & $\begin{array}{l}\text { Masking con- } \\
\text { troversial } \\
\text { practices }\end{array}$ & $\begin{array}{l}\text { - Dominant managerial coalition "compartmentalizes" the organization: } \\
\text { "There was this 'inner circle' around the CEO, all of them were fundraisers. They were very close. The head of the fundraising department } \\
\text { had a very strong position. He was very powerful. He had full legitimacy." (interview, intern, 2019) } \\
\text { "There were two groups in the organization, those that would earn the money and those that would spend it." (interview, manager, 2009) } \\
\text { - Managerialists hide specific practices from volunteers and idealist staff: } \\
\text { "There was this 'inner circle' around the former CEO, they knew [about the new business practices]. They were informed. But nobody else } \\
\text { knew, that's true." (interview, volunteer, 2008) } \\
\text { "We were unaware of the compensation of freelancers and consultants. I believe we [board members] should have been aware of such remu- } \\
\text { neration schemes." (interview, board member, 2008) } \\
\text { "There was absolutely no reason to inform the volunteer groups about the fundraising practices [in the eyes of the top managers in charge]. } \\
\text { There was simply no reason." (interview, intern, 2019) }\end{array}$ \\
\hline $\begin{array}{l}\text { Political } \\
\text { effects }\end{array}$ & $\begin{array}{l}\text { Distorted } \\
\text { power bal- } \\
\text { ance }\end{array}$ & $\begin{array}{l}\text { - Managerialists gain disproportionate influence over organizational identity: } \\
\text { "[Managerialists] knew how to make money. Their overall goal was to increase revenues. In fact, disasters do. They knew how to exploit dis- } \\
\text { asters. The organization was split in two. While some earned the money, others spent the money. However, there was never any doubt who } \\
\text { was in control [the managerialists]." (interview, intern, 2019) } \\
\text { "Without any doubt UNICEF Germany, has been purely a fundraising organization. We could be a great organization if we didn't have to raise } \\
\text { funds. Then, we would be able to focus exclusively on children's rights. Our problem is that we only measure our success by how much } \\
\text { money we earn." (interview, board member, 2008) } \\
\text { - Idealists feel disenfranchised: } \\
\text { "We were not in a position to involve everyone. ... We have modernized, we are more professional now, we are more digital. What do you do } \\
\text { with the long-serving members [idealists]? You can't simply get rid of them." (interview, board member, 2008) } \\
\text { "Many staff members in the headquarters [idealists] do not fully grasp what actually happened. And they don't understand [the new manageri- } \\
\text { alist dominance]." (interview, top manager, 2008) } \\
\text { "We did not [anymore] expect to be part of these processes [talking about important decisions]" (interview, board member, 2008) }\end{array}$ \\
\hline
\end{tabular}




\begin{tabular}{|c|c|c|}
\hline & $\begin{array}{l}\text { Disguised } \\
\text { conflict }\end{array}$ & $\begin{array}{l}\text { - Board and top management ignore the underlying identity tensions: } \\
\text { "In the crisis itself, the board was then suddenly, surprised and overwhelmed. ... And that despite the fact that the board members, each of } \\
\text { them had tremendous experience in leading and managing organizations. That's what makes you so worrying, what had we missed, why didn't } \\
\text { all the experience play out at that point?" (interview, board member, 2008) } \\
\text { "We left too long a leash. That was a mistake. We should have been much more involved [to spot the growing tensions and discomfort in the } \\
\text { organization]" (interview, board member, 2008) } \\
\text { - Idealists become increasingly dissatisfied: } \\
\text { "The watershed wasn't the crisis. That was before. There was growing criticism and dissatisfaction of the people who worked for UNICEF." } \\
\text { (interview, board member, 2008) } \\
\text { "I recall an increasing number of dissatisfied people who contacted me. Since I was not the chairperson anymore, I had no formal role. There- } \\
\text { fore, it was easier to approach me with such concerns." (interview, board member, 2010) }\end{array}$ \\
\hline
\end{tabular}


Table 3: Revelation of Identity Breach: Examples of Empirical Material

\begin{tabular}{|c|c|c|}
\hline $\begin{array}{l}\text { Aggre- } \\
\text { gate }\end{array}$ & $\begin{array}{l}\text { Second order } \\
\text { themes }\end{array}$ & Examples of empirical material \\
\hline $\begin{array}{l}\text { Political } \\
\text { strategies }\end{array}$ & $\begin{array}{l}\text { Revealing } \\
\text { identity viola- } \\
\text { tions }\end{array}$ & 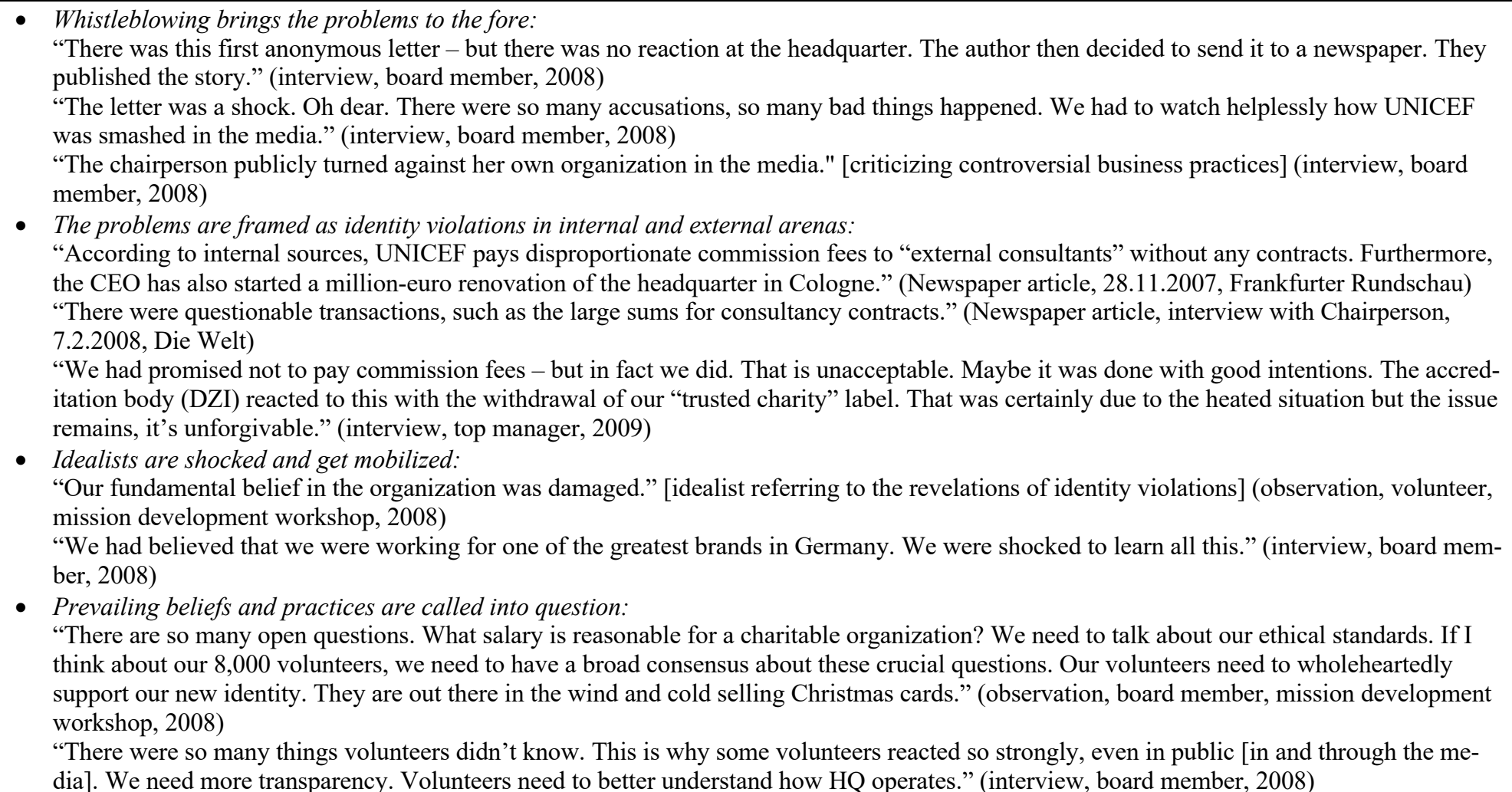 \\
\hline
\end{tabular}




\begin{tabular}{|c|c|c|}
\hline & $\begin{array}{l}\text { Defending } \\
\text { prevailing } \\
\text { identity be- } \\
\text { liefs }\end{array}$ & $\begin{array}{l}\text { Managerialists justify prevailing practices: } \\
\text { "We were growing; we were successful, hugely successful. What could potentially be wrong with that?" (interview, top manager, 2009) } \\
\text { "Our fundraising worked very well. We were successful in online fundraising and our innovative SMS tools. We were ahead of the competi- } \\
\text { tion. Why should anyone question those practices?" (interview, top manager, 2008) } \\
\text { "A retired member of my top management team worked as an external consultant for us. We got attacked for this because people expected } \\
\text { him to work as a volunteer without salary - since he had reached retirement [and would not need a salary anymore]." (Newspaper article, in- } \\
\text { terview with CEO 1, Verbändereport, 2013) } \\
\text { Managerialists blame key idealists for politicking and power plays: } \\
\text { "They [the idealists] tried to divide us." (interview, top manager, 2008) } \\
\text { "I cannot believe it. They [idealist volunteers] took the UNICEF logo and wrote down the most incredible accusations and demanded all sorts } \\
\text { of actions, and then they sent it to a newspaper. Without even talking to us [the headquarter]." (interview, top manager, 2008) } \\
\text { "There was an internal conflict and the protagonists transported their issues to the media. If there had been some mechanism in place, at least it } \\
\text { would have remained within UNICEF." (interview, top manager, 2009) }\end{array}$ \\
\hline \multirow{2}{*}{$\begin{array}{l}\text { Political } \\
\text { effects }\end{array}$} & $\begin{array}{l}\text { Reversal of } \\
\text { power bal- } \\
\text { ance }\end{array}$ & $\begin{array}{l}\text { - Idealists gain the upper hand in discussion about organizational identity: } \\
\text { "In light of the permanent media coverage and public pressure, [managerialists] were forced to respond." (observation, mission development } \\
\text { workshop, 2008) } \\
\text { "This is our model, our idea of UNICEF. I believe some people [managerialists] will be surprised to learn how different our views are." (ob- } \\
\text { servation, mission development workshop, 2008) } \\
\text { - Managerialists face unprecedented pressure: } \\
\text { "We need more accountability. We have to explain better how we use our money, to our donors and the public. We have to engage in an open } \\
\text { dialogue about this criticism." (observation, mission development workshop, 2008) } \\
\text { "There were new accusations by the media every day, volunteers who accused UNICEF of the strangest things without any sense of responsi- } \\
\text { bility...that was shocking." (interview, board member, 2008) } \\
\text { "The [managerialist] CEO and key people in the fundraising team left, we were headless to a certain degree." (observation, top manager, } \\
\text { 2009) }\end{array}$ \\
\hline & Open conflict & $\begin{array}{l}\text { - Idealist and managerialists openly disagree about what the organization stands for: } \\
\text { "There was considerable disagreement about very basic questions that should be easy to answer for any organization." (interview, board mem- } \\
\text { ber, 2008) } \\
\text { "We were all shocked and frightened. The magnitude of the crisis was surprising. Whenever we thought this cannot get worse, it did." (inter- } \\
\text { view, board member, 2008) } \\
\text { - Idealists and managerialists are engaged in a mediatized conflict: } \\
\text { "[Managerialist CEO 1] and [idealist Chairperson 2] were stabbing each other in the back to gain power. And they used the media to do so." } \\
\text { [interview, board member, 2008] } \\
\text { "She [Chairperson 2] clearly wanted power. That was not a good match with our powerful CEO 1. They were like two trains racing towards } \\
\text { each other - at full speed. There were no means to stop them. At first, she could not push her [idealist] topics through. Then she decided to play } \\
\text { 'hardball'." (interview, top manager, 2008) } \\
\text { Idealist Chairperson } 2 \text { secretly provides public prosecution office with information against [managerialist] CEO. (Spiegel, 4.2.2008) }\end{array}$ \\
\hline
\end{tabular}


Table 4: Identity Reconstruction: Examples of Empirical Material

\begin{tabular}{|c|c|c|}
\hline $\begin{array}{l}\text { Aggre- } \\
\text { gate }\end{array}$ & $\begin{array}{l}\text { Second order } \\
\text { themes }\end{array}$ & Examples of empirical material \\
\hline $\begin{array}{l}\text { Political } \\
\text { strategies }\end{array}$ & $\begin{array}{l}\text { Arguing for } \\
\text { alternative } \\
\text { identity con- } \\
\text { structions }\end{array}$ & 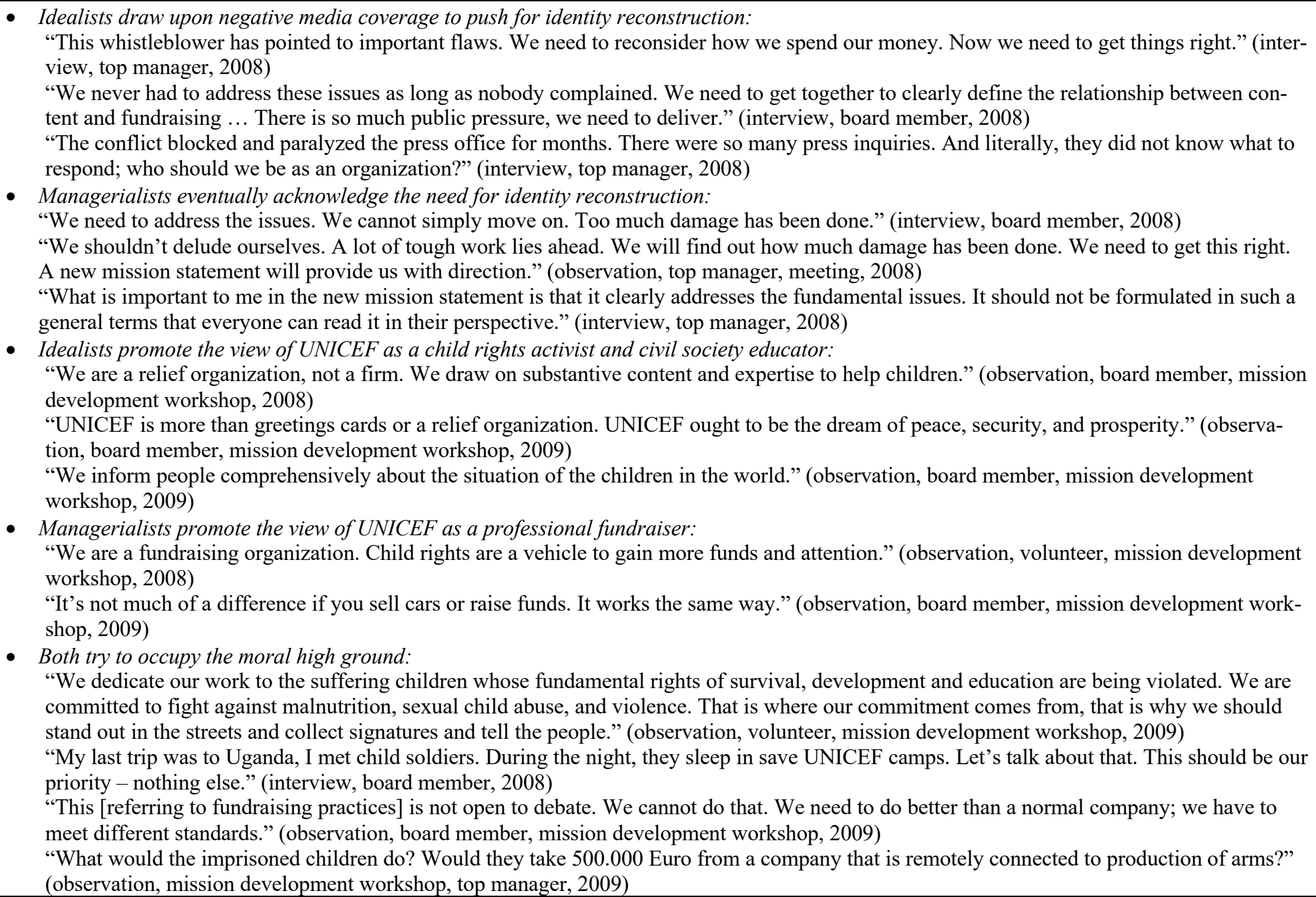 \\
\hline
\end{tabular}




\begin{tabular}{|c|c|c|}
\hline & $\begin{array}{l}\text { orging a } \\
\text { mpromise } \\
\text { identity }\end{array}$ & $\begin{array}{l}\text { - Both sides negotiate priorities: } \\
\text { "Fundraising decisions also have to be value-based decisions. There are limits to fundraising. We need to set those limits in line with our val- } \\
\text { ues." (observation, board member, mission development workshop, 2009) } \\
\text { "Since we deliberately choose to work with our volunteers, we have so far shied away from defining an ideal skill profile for volunteers in this } \\
\text { respect. But that's a tough topic to tackle." (interview, top manager, 2009) } \\
\text { - Managerialists and idealists engage in behind-the-scene negotiation tactics: } \\
\text { Behind the scenes, idealists try to influence important decisions: New Chairperson } 3 \text { is approached by idealists during a coffee break who con- } \\
\text { vince him to put topic of interest for volunteers on agenda of the board. The idealist manager later explains her move: "The squeaky wheel gets } \\
\text { the grease, it was important in this situation to draw attention to our [idealist] agenda." (observation, mission development workshop, 2009) } \\
\text { During a break, an idealist middle manager tries to convince managerialist colleagues in a hallway conversation: "We promote volunteer activ- } \\
\text { ism... for the well-being of children and their rights." (observation, middle manager, mission development workshop, 2009) } \\
\text { - Idealists and managerialists are ready to compromise on key points: } \\
\text { "This is about our organizational culture. We do not want to be perceived as a cold-blooded profit-maximizing machine." (observation, mana- } \\
\text { gerialist board member, mission development workshop, 2009) } \\
\text { "I am open for compromise here." [talking about controversial fundraising practices] (observation, idealist board member, mission develop- } \\
\text { ment workshop, 2009) } \\
\text { "Yes, I do understand now we need to see ourselves even more as a children's rights organization in the future. So I opt for that." (observation, } \\
\text { managerialist board member, mission development workshop, 2009) } \\
\text { "We decided to strengthen the role of volunteers a lot in the future [...] This is an important decision and a big change." [about a decision to } \\
\text { emphasize important role of volunteers in the new mission statement] (observation, managerialist board member, mission development pro- } \\
\text { cess, 2009) }\end{array}$ \\
\hline & $\begin{array}{l}\text { Restored } \\
\text { power bal- } \\
\text { ance }\end{array}$ & $\begin{array}{l}\text { - Managerialists and idealists find a balance they appreciate and can live with: } \\
\text { "There are so many different people and different views. It is hard to believe that we decide from now on it works like this and we throw the } \\
\text { old away, it's no longer good. Then you lose good people. We take them with us." (interview, board member, 2009) } \\
\text { "While our new chairman is an accomplished entrepreneur, we now have an [idealist] CEO who deeply cares about content. This is very differ- } \\
\text { ent from before the crisis. We now have somebody who actually listens to and understands our [idealist] topics and issues." (observation, strat- } \\
\text { egy workshop, 2010) }\end{array}$ \\
\hline $\begin{array}{l}\text { Political } \\
\text { effects }\end{array}$ & $\begin{array}{l}\text { Orchestrated } \\
\text { consensus }\end{array}$ & $\begin{array}{l}\text { - Differences in identity beliefs and values are acknowledged and accepted: } \\
\text { "We finally understood that we need to involve everyone. In particular, employees and volunteers should be involved in the mission develop- } \\
\text { ment workshops." (observation, top manager, planning meeting for mission development process, 2008) } \\
\text { "We involved many different groups in the process. Everyone had a say." (interview, top manager, 2009) } \\
\text { "For many people, it was a new experience to discuss openly [...] At times, it was difficult to lead the discussion." (interview, board member, } \\
\text { 2009) } \\
\text { The key managerialists and idealists gather behind the orchestrated compromise: } \\
\text { "This is a crucial point [to back the compromise]. There are so many different opinions here - even about the crisis, which we now try to cau- } \\
\text { tiously lead to a consensus." (interview, top manager, 2009) } \\
\text { "It does not help to come up with a consensus that only half of us share. We discuss this with different groups with different perspectives and } \\
\text { each perspective has to be represented by someone. There are different legitimate positions; a fundraiser has a different perspective than the PR } \\
\text { expert. ... Those need to be reconciled." (interview, top manager, 2009) }\end{array}$ \\
\hline
\end{tabular}


Table 5: Enacting the Reconstructed Identity: Examples of Empirical Material

\begin{tabular}{|c|c|c|}
\hline $\begin{array}{l}\text { Aggre- } \\
\text { gate }\end{array}$ & $\begin{array}{l}\text { Second order } \\
\text { themes }\end{array}$ & Examples of empirical material \\
\hline \multirow[t]{2}{*}{$\begin{array}{l}\text { Political } \\
\text { strategies }\end{array}$} & $\begin{array}{l}\text { Enforcing } \\
\text { compromise } \\
\text { on identity }\end{array}$ & $\begin{array}{l}\text { - Key managerialists and idealists declare the identity process completed: } \\
\text { "It goes without saying that our employees and supporters were disturbed by the internal conflict and the subsequent public critic. This chapter } \\
\text { is closed now." (Annual report, 2008) } \\
\text { - The new mission statement is communicated and spread in internal and external arenas: } \\
\text { "We know who we are now. We are a movement, our volunteers support us. We focus on impact. Our donors know we have the biggest lever- } \\
\text { age. If you donate, your money will have an impact - bigger than with any other organization." (interview, top manager, 2011) } \\
\text { Top manager explains how the new mission statement is communicated so forcefully that is seems impossible to disagree: "We had this great } \\
\text { inclusive process lasting many months involving so many people, we now have the mission statement visibly on the wall in the headquarter } \\
\text { and the volunteers' offices. We will not open that box anymore." (observation, volunteer workshop, 2011) }\end{array}$ \\
\hline & $\begin{array}{l}\text { Maintaining } \\
\text { the compro- } \\
\text { mise on iden- } \\
\text { tity }\end{array}$ & $\begin{array}{l}\text { - Managers and organizational members continue to re-negotiate identity issues backstage: } \\
\text { "Our volunteers do not like our fundraising activities in public spaces. They see it as a 'dubious practice' to send professional fundraisers to } \\
\text { ask random people on the street for donations. We cannot ignore their opinion and just do what we believe is right thing to do. We have to } \\
\text { inform them, we need to engage in those discussions. Each decision is taken very carefully; we ask ourselves how the volunteers and the mem- } \\
\text { bers and the public will react." (observation, top manager, strategy workshop 2017) } \\
\text { "We have also defined non-financial KPIs now. This is a major step towards acknowledging our [idealist] contributions to UNICEFs mission." } \\
\text { (interview, top manager, 2017) }\end{array}$ \\
\hline \multirow[b]{2}{*}{$\begin{array}{l}\text { Political } \\
\text { effects }\end{array}$} & $\begin{array}{l}\text { Effectuation } \\
\text { of power bal- } \\
\text { ance }\end{array}$ & $\begin{array}{l}\text { - Managerialists and idealists support the effectuation of power balance: } \\
\text { "We have two goals, one is to maximize donations, the other goal is related to content. It's a balance. We stand up for children's rights in Ger- } \\
\text { many but also inform about the situation of children worldwide. We also encourage people to get involved in Germany, to join us as volun- } \\
\text { teers." (interview, top manager, 2017) } \\
\text { "Both aspects [fundraising and child rights advocacy] are important. It's not about taking something from one person and giving it to another. } \\
\text { There should be a reasonable balance." (observation, board meeting, 2010) } \\
\text { "We needed to pay heed to the weighting between raising funds and child rights. We agreed on that in the strategy process. You cannot say } \\
\text { that one is more important than the other. Because one is a prerequisite for the other. And both are important. (interview, top manager, 2010) }\end{array}$ \\
\hline & $\begin{array}{l}\text { Sustained } \\
\text { consensus }\end{array}$ & $\begin{array}{l}\text { - Consensus over identity is enforced: } \\
\text { "Trust is the most important thing for us, specifically in the fundraising market. While volunteers and donors demand transparency, our volun- } \\
\text { teers have a completely different concept of transparency. For donors transparency means being present on the billboards. In contrast, volun- } \\
\text { teers want involvement in and accountability of major decisions; they want their voice to be heard - in the board and elsewhere. We need to } \\
\text { work on this." (observation, top manager, marketing workshop, 2012) } \\
\text { "We have now the big chance to move on. We analyzed in detail during the crisis where do we come from in the past, what happened and how } \\
\text { we have the unique chance to develop a coherent view." (observation, top manager, marketing workshop, 2011) } \\
\text { - Managerialists and idealists continue to point to underlying identity tensions: } \\
\text { "We have this standard notion of "HQ views it this or that way" - as if we were a homogeneous crowd." (interview, top manager, 2010) } \\
\text { "Fundraising is one of many goals of UNICEF. It is not the only purpose but we have content-driven goals as well. These multiple goals make } \\
\text { us different from a for-profit company and we need to balance them carefully." (interview, top manager, 2017) }\end{array}$ \\
\hline
\end{tabular}


Figure 1: Key Events and Actors in Identity Breach and Reconstruction in UNICEF Germany 2007-2019

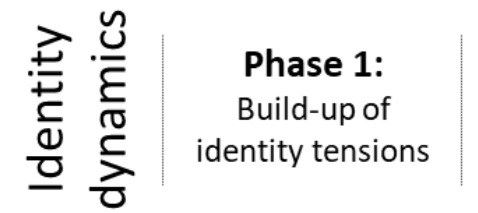

으
Phase 2:

Revelation of

\section{Nov. 2007}

Initial article on

fraud allegations

published

9

Dec. 2007

Public

investigation

starts

保

Feb. 2008

'Trusted

charity' label

withdrawn
Phase 3:

Identity

reconstruction
Phase 4:

Enactment of

reconstructed identity
Oct. 2008

Public

investigation

suspended

suspend

Dec. 2008

Income

drops by

$24 \%$

$24 \%$
Jun. 2009 Jan. 2010

Board Implemen-

approves tation of

new mission

mission
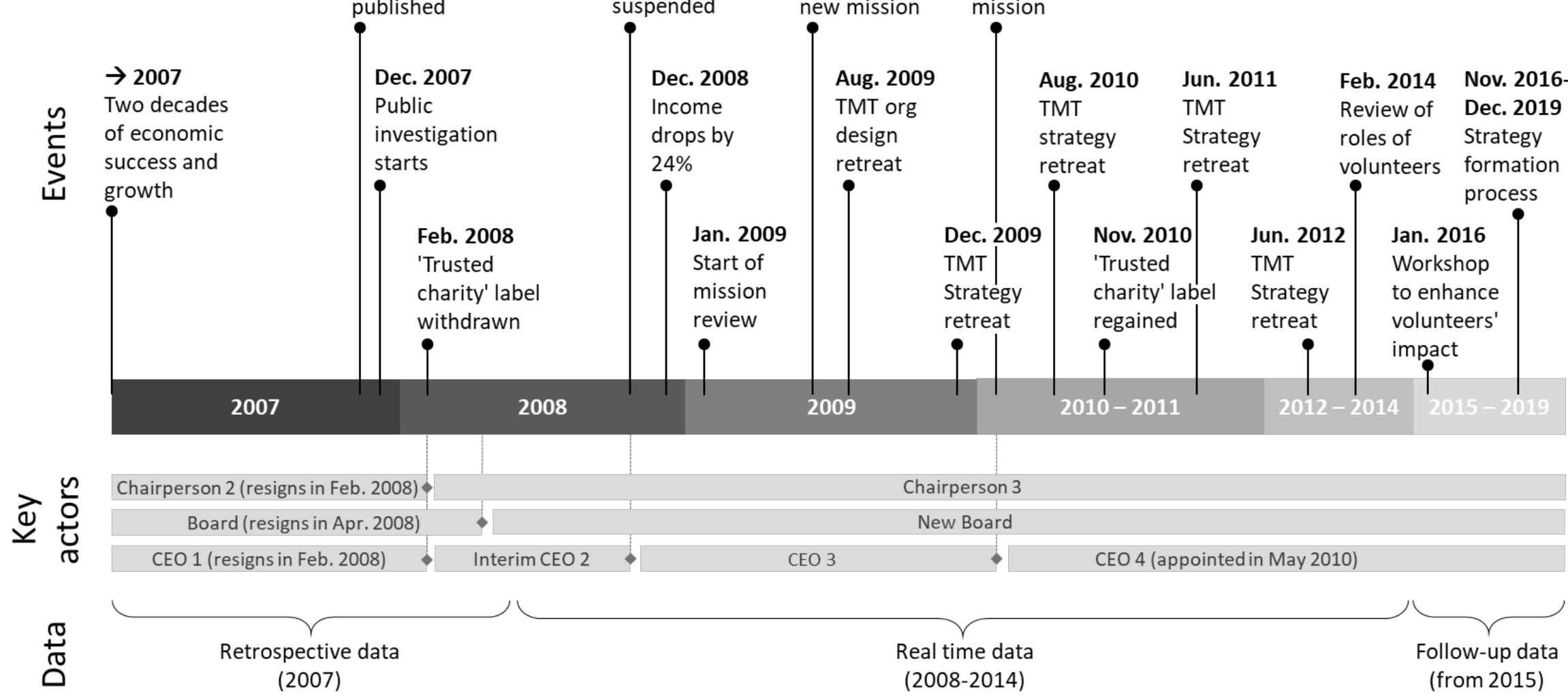


\section{Figure 2: Data Structure}

- Managerialists promote their identity beliefs in internal and external arenas

- Board does not question managerialist identity beliefs or new business practices

- Dominant managerial coalition "compartmentalizes" the organization

- Managerialists hide specific practices from volunteers and idealist staff
Political strategies

Normalizing specific identity

beliefs

Masking controversial practices

Build-up of dentity tensions

- Managerialists gain disproportionate influence over organizational identity

- Idealists feel disenfranchised

- Board and top management ignore the underlying identity tensions

- Idealists become increasingly dissatisfied

- Whistleblowing brings the problems to the fore

- The problems are framed as identity violations in internal and external arenas

- Idealists are shocked and get mobilized

- Prevailing beliefs and practices are called into question

- Managerialists justify prevailing practices

- Managerialists blame key idealists for politicking and power plays

- Idealists gain the upper hand in discussion about organizational identity

- Managerialists face unprecedented pressure

- Idealists and managerialists openly disagree about what the organization stands for

- Managerialists and idealists are engaged in a mediatized conflict

\section{Political strategies}

Revealing identity violations

\section{Defending prevailing identity}

beliefs

$\sqrt{\text { Revelation of }}$

identity breach

\begin{tabular}{|l|} 
Political effects \\
Reversal of power balance \\
Open conflict \\
\hline
\end{tabular}




\section{Figure 2: Data structure (continued)}

- Idealists draw upon negative media coverage to push for identity reconstruction

- Managerialists eventually acknowledge the need for identity reconstruction

- Idealists promote the view of UNICEF as child rights' activist \& civil society educator

- Managerialists promote the view of UNICEF as a professional fundraiser

- Both try to occupy moral high ground

- Both sides negotiate priorities

- Managerialists and idealists engage in behind the scenes negotiation tactics

- Idealists and managerialists are ready to compromise on key points

- Managerialists and idealists find a balance they appreciate and can live with

- Differences in identity beliefs and values are acknowledged and accepted

- The key managerialists and idealists gather behind the orchestrated compromise

- Key managerialists and idealists declare the identity process completed

- The new mission statement is communicated and spread in internal and external arenas

Political strategies

- Managers and organizational members continue to re-negotiate identity issues backstage

- Managerialists and idealists support the effectuation of power balance

- Consensus over identity is enforced

- Managerialists and idealists continue to point to underlying identity tensions

olitical strategies

Arguing for alternative identity

constructions

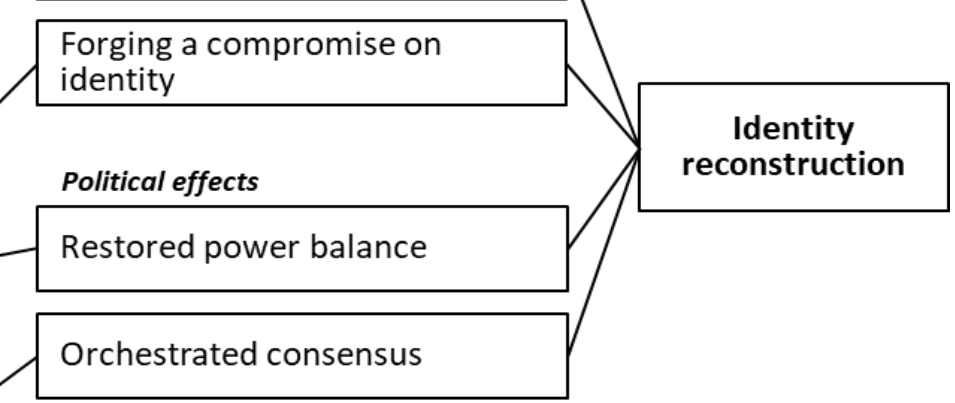

Enforcing compromise on

identity

Maintaining the compromise

Enactment

of reconstructed

Political effects

identity

Effectuation of power balance

Sustained consensus 
Figure 3: A Process Model of Organizational Identity Breach and Reconstruction

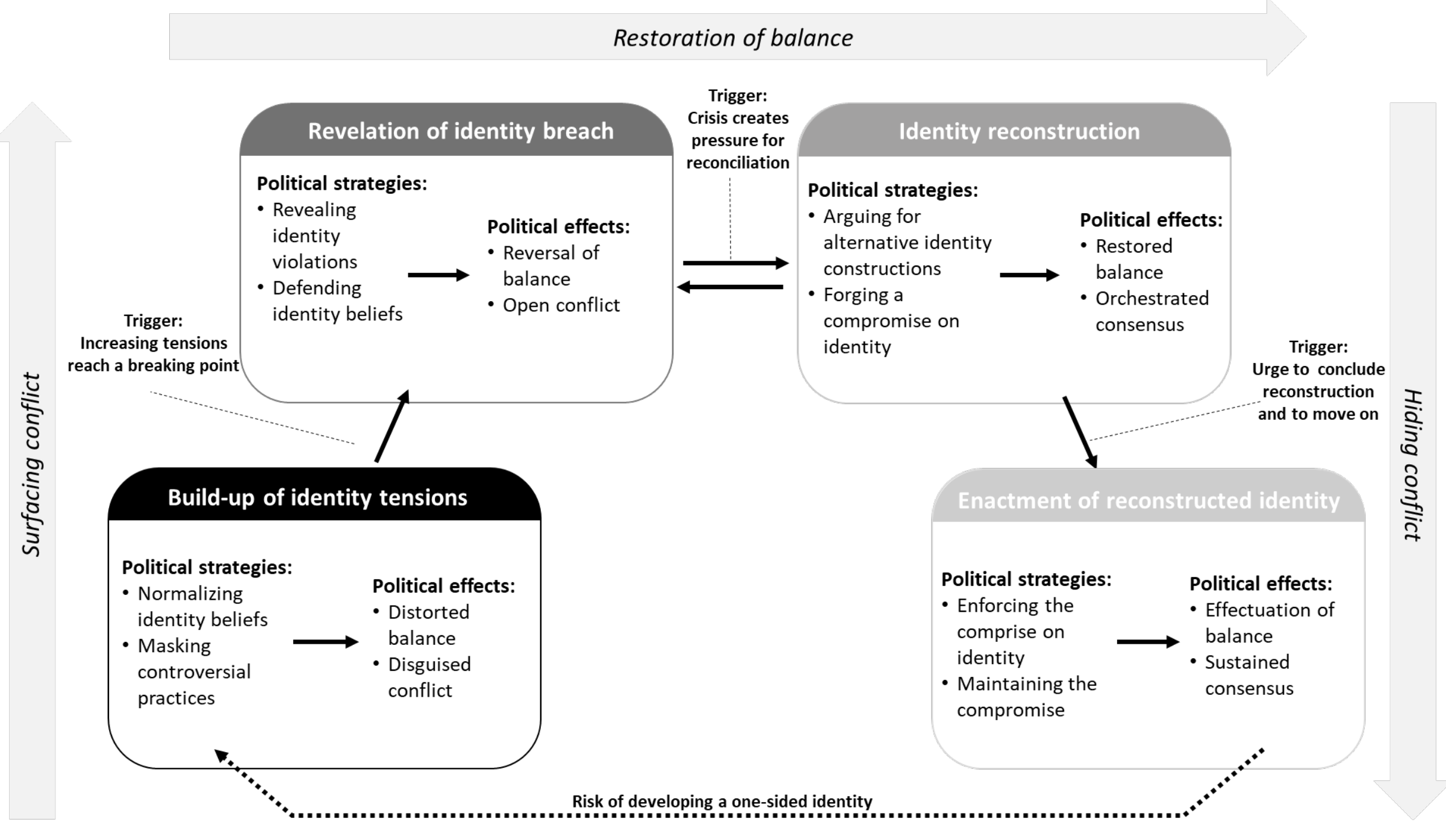




\section{Biographies:}

Claus D. Jacobs (claus.jacobs@kpm.unibe.ch) is Professor of Public Management and Organization and co-director of University of Bern's KPM Center for Public Management. He is an Associate Fellow of Saïd Business School, University of Oxford, and long time faculty to its executive education programs. He holds a $\mathrm{PhD}$ from the University of Dublin, Trinity College. His research focuses on organizational identity change, breach and reconstruction, strategy work in pluralistic settings including strategic management and organizational transformation in public sector organizations.

Karin Kreutzer is Professor of Social Business and co-director of the Impact Institute at EBS Universität für Wirtschaft und Recht, Germany. She held a visiting position at the Institute for Social Innovation at ESADE Business School in Barcelona and received her doctorate from the University of St.Gallen, Switzerland. Her research focuses on how organizations create social impact. This work deals with multiplicity and processes of identity change in organizations, and investigates phenomena such as managerialism and cross-sector social partnerships. She serves on the board of social enterprises and advices nonprofit organizations, social entrepreneurs and supporting organizations.

Eero Vaara (eero.vaara@sbs.ox.ac.uk) is Professor in Organisations and Impact at Saïd Business School at University of Oxford. He also serves as Visiting Distinguished Professor at Aalto University. He received his PhD from Helsinki School of Economics. His research focuses on organizational and strategic change that he examines primarily from discursive and narrative perspectives. This work deals with strategy process and practice research, studies of radical change such as mergers and acquisitions, work on institutional change and legitimation, research on multinational corporations and globalization, and historical analysis of management and organizations. 